Çalışkan, E. (2019). How Do Educational Researchers Utilize from Social Media? Bartın University Journal of Faculty of Education, 8(1), 179-207.

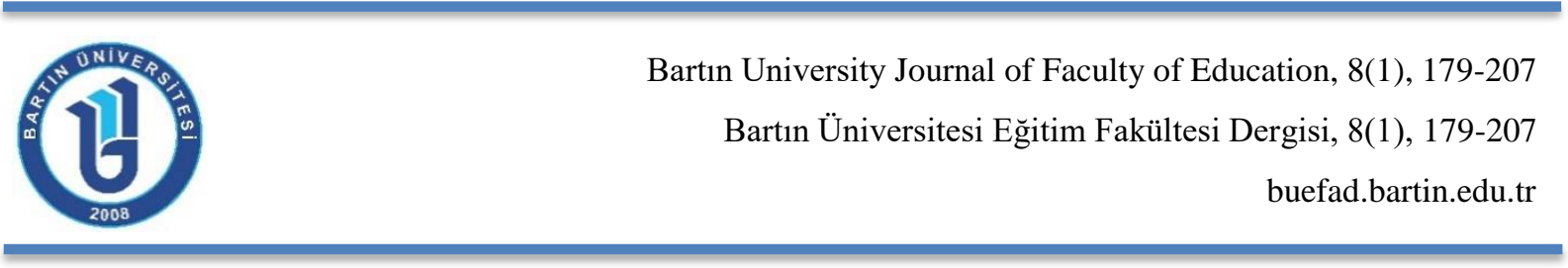

\title{
How Do Educational Researchers Utilize from Social Media?
}

\author{
Erkan Çalışkan*a
}

\begin{tabular}{l} 
Article Info \\
\hline DOI: $10.14686 /$ buefad.463514 \\
\hline Article History: \\
Received 25.11.2018 \\
Accepted 22.12.2018 \\
Published $\quad 01.02 .2019$ \\
\hline Keywords: \\
Educational researchers, \\
Educational studies, \\
Social media, \\
Web 2.0. \\
\hline Article Type: Research Article \\
\end{tabular}

\begin{abstract}
Social media is very popular on the Internet and individuals utilize from social media in different ways. This exploratory research investigated the educational researchers' social media uses and their opinions about using social media as a research, teaching and learning environment for educational purposes within a sample of Turkish educational researchers. A total of 207 researchers participated in this study. The results showed that $62 \%$ of the researchers utilized from social media for their previous educational studies and $90 \%$ of them planned to utilize from social media for their educational studies in the near future. Most of the educational researchers think positive about the usage of social media within educational studies, but they have complained about the insufficiency of literature. It has been seen that the researchers' study at the Department of Computer and Instruction Technologies Education use social media more effective and younger researchers utilize from social media more and think to utilize more in faculties of education. At the same time, researchers who use social media more effectively in their daily lives, benefit more from social media in their educational studies. Some seminars can be organized to overcome the technical knowledge deficiencies of educational researchers. Education researchers can be encouraged to adopt and use social media elements.
\end{abstract}

\section{Eŭitim Araștırmacıları Sosyal Medyadan Nasıl Yararlanmaktadır?}

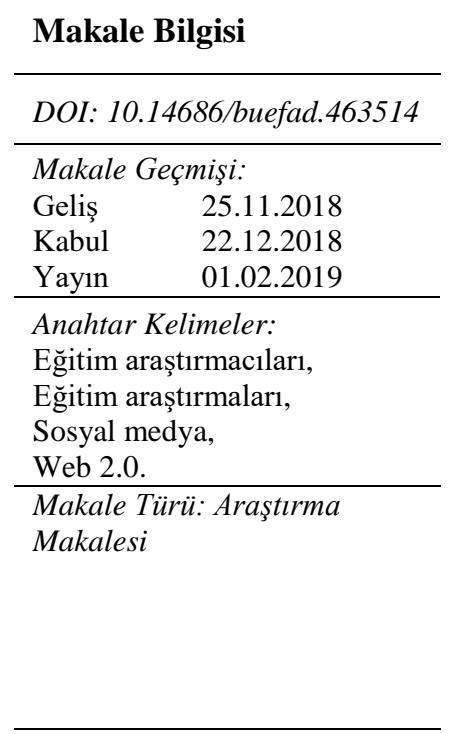

Öz

Günümüzde kullanım oranları gittikçe artan sosyal medyadan bireyler farklı yollarla faydalanmaktadırlar. Bu keşif araştırmasında, eğitim araştırmacılarının sosyal medya kullanımları ve sosyal medyayı eğitim amaçlı bir araştırma, öğretim ve öğrenim ortamı olarak kullanmaları hakkındaki görüşleri araştırılmıştır. Bu çalışmaya eğitim alanında çalışma yapan toplam 207 araştırmacı katılmıştır. Sonuçlar, araştırmacıların \%62'sinin, önceki eğitim çalışmaları için sosyal medyadan yararlandığını ve bunların \%90'ının, yakın gelecekte de eğitim çalıșmaları için sosyal medyadan yararlanmayı planladıklarını göstermektedir. Eğitim araştırmacılarının çoğu, eğitim çalışmalarında sosyal medyanın kullanımı hakkında olumlu düşünceye sahiptirler. Ancak eğitim çalışmalarında sosyal medya kullanımıyla ilgili literatürün yetersizliğinden şikayetçidirler. Çalışmaya katılan araştırmacılardan Bilgisayar ve Öğretim Teknolojileri Eğitimi Bölümü'nde çalıșan akademik personelin sosyal medyadan daha etkili yararlandıkları görülmüştür. Genç araştırmacıların sosyal medyayı daha çok kullanma eğiliminde oldukları bulunmuştur. Aynı zamanda sosyal medyayı günlük yaşamlarında daha etkin kullanan araştırmacılar eğitim çalışmalarında da sosyal medyadan daha yoğun yararlanmaktadırlar. Eğitim araştırmacılarının teknik bilgi eksikliklerinin giderilerek sosyal medya ögelerini benimsemeleri ve kullanmaları teşvik edilebilir.

\footnotetext{
*Corresponding Author: erkancaliskan@ohu.edu.tr

a Asst.Prof., Nigde Omer Halisdemir University, Nigde/Turkey, http://orcid.org/0000-0002-2309-1406
} 


\section{Introduction}

Web 2.0 was defined as the second generation of the web-based services and applications in 2004 (Poynter, 2010) and individuals started to socialize, collaborate, and share via the Internet (Lamb \& Johnson, 2007). With Web 2.0 technologies, Internet users can chat, interpret events and news, and share photo and video, instead of viewing static web pages (Gonzales, Vodicka, \& White, 2011). These actions constitute social media. Social media is defined as "a group of Internet-based applications that build on the ideological and technological foundations of Web 2.0 and that allow the creation and exchange of user-generated content" (Kaplan \& Haenlein, 2010: 61). Social media offers some features to people to cooperate, collaborate, and share through information and communication technologies and social media interactions can occur through a variety of ways, from web browsers to smartphone applications (Castro, 2012). Social media connections may involve one-to-one (email, instant messaging), one-to-many (blogs, web postings), or many-to-many (wikis) communication (Murthy, 2008; Poynter, 2010).

The primary purpose of using social media is entertainment (Smith, Salaway, \& Caruso, 2009). On the other hand, the capacity of social media seems to be unlimited (Tyson, 2010) and educational specialists have positive attitudes towards usable by students and instructors for educational purposes (Poellhuber \& Anderson, 2011; Wankel, 2009). At the same time, students had already wanted to use Web 2.0 and social media technologies for class activities (Mazman \& Koçak-Usluel, 2010; Yoo \& Huang, 2011), because of they got bored with ordinary classroom activities. This new generation of learners called as "digital natives" by Prensky (2001a; 2001b; 2005). have different skills and interests. So some changes are needed in education systems (Moll \& Nielsen, 2017). With the steadily increasing of usage of social media by students, educators have begun to utilize from social media services and tools for teaching subjects (Bozanta \& Mardikyan, 2017; Chen \& Bryer, 2012; Ferriter, 2010-2011; Yoo \& Huang, 2011). At this point, educators have seen that they can provide some important opportunities to enhance students' learning experiences with these environments (Borštnar, 2012; Bryant, 2006; McLoughlin \& Lee, 2007; Selwyn, 2007; Yoo \& Huang, 2011). In their studies, Aspey (2011) and Castro (2012) found that students join instruction activities easier with online lessons than traditional lessons and educators like to use social media in their teaching process. Back (2013) stated that some social media tools such as Facebook are playing an important role for language learners. Similarly, Meishar-Tal, Kurtz, and Pieterse (2012) used Facebook as a learning management system (LMS) in their study. At the end of their study, the students were satisfied with learning in Facebook and they wanted to continue using these online study groups in further courses. For academic success, Friesen and Lowe (2012) and Veletsianos, Kimmons, and French (2013) point out that social networking and other social media tools are new teaching environments for social learning experiences in education. At the same time, we can see that using social media for educational purposes in different areas. For example; there are some researches interested with interior architecture (Güler, 2015), sport management (O'Boyle, 2014), marketing and management (Al-Bahrani, Patel, \& Sheridan, 2015), health and medical education (Galiatsatos, Porto-Carreiro, Hayashi, Zakaria, \& Christmas, 2016; Maloney, Moss, \& Ilic, 2014; Roy, Taylor, Cheston, Flickinger, \& Chisolm, 2016) and others. Most of studies reveal lots of advantages of using social media for higher education training processes (Ada, Stansfield, \& Baxter, 2017; Chu, Capio, van Aalst, \& Cheng, 2017; Gülbahar, Rapp, Kilis, \& Sitnikova, 2017; Güler, 2015; Matzat \& Vrieling, 2016; Smith, 2016).

Although there are many studies in which social media is used in educational terms, it is mentioned that there is a need for theoretical research in the literature in recent years (Greenhow \& Lewin, 2016). According to Gülbahar et al. (2017) and Matzat and Vrieling (2016), unsureness of how to soundly integrate social media in teaching from an instructional design perspective and how to use social media in educational settings are important challenges for the field. Every study is trying different things (Greenhow \& Lewin, 2016). Evans (2014) states that the use of social media in higher education is still at an early stage. To avoid misuse of using social media in learning activities, academics, and other staff will need to consider how and when integrating social media into those activities (Conway, 2011). The role of the educator is very important in these studies (Callaghan \& Bower, 2012). The motivations of educators with their personal and pedagogical beliefs are among the key factors for successful technology integration in education (Ertmer, 2005). However, to date, there is no more study that has examined the educational researchers' social media uses and their opinions about using social media as a research and study environment or data source. Pimmer, Linxen and Gröhbiel (2012) conducted an exploratory research with health educators to use social media as educational environment. Çelik, Kaplan Akıllı and Onuk (2014) examined the social media perceptions of academicians and the educational potential of social media in terms of educators. Rochez (2015) examined education historians' use of digital technologies and social media, Li and 
Greenhow (2015) explored how educational scholars incorporated the social media, Donelan's (2016) focus was on how Science, Technology, Engineering, and Mathematics (STEM) academics use social media, Knight and Kaye (2016) compared the academics and students usage of Twitter in academic context, and Manca and Ranieri (2016) tried to provide some empirical evidence on how higher education scholars are using social media for personal, teaching and professional purposes. A new movement has begun to appear in model studies (e.g. Bozanta \& Mardikyan, 2017; Brech, Messer, Schee, Rauschnabel, \& Ivens, 2017; Garcia \& Costa Silva 2017; Greenhow \& Lewin, 2016). We need more educational researches for model studies. At the same time, there has been a lack of examining education scholars' usage of social media (Kimmons \& Veletsianos, 2016; Li \& Greenhow, 2015; Manca \& Ranieri, 2017; Veletsianos \& Kimmons, 2016). It is important to study the situation of the educational researchers for the teaching process and research designs with the studies conducted (Evans, 2014). However, there are not enough studies examining the tendency of educational researchers to use social media as a research and teaching environment. Also, Aydin (2012) and Çelik and colleagues (2014) stated that there has not many researches on utilizing from social media as an educational environment in Turkey. In the study conducted by Çelik et al. (2014), which is one of the rare studies conducted within the scope of national studies, not only educational researchers, but also educators from the fields such as engineering and natural sciences were included in the study. The most important responsibility for educational researchers is eliminating the theoretical and empirical lack of social media integration into the teaching process (Evans, 2014). The main purpose of this research is to determine the educational researchers' use of social media in their daily lives and educational studies and to examine their views on research design for the use of social media in educational research. Since the research was carried out in an exploratory type, it was mostly focused on what and how questions, and also the relationships of education researchers with the use of social media in terms of gender, age, experience, and departments. For purposes of this study, the following five questions were addressed:

(1) What is the knowledge level of educational researchers about Web 2.0 and social media?

(2) How do scholars in the education field use social media?

(3) What is the state of utilizing from social media of educational researchers within educational researches?

(4) Is there any relation between the demographic characters of researchers and the using social media for daily life or educational purposes?

(5) What are the researchers' opinions about using social media within educational studies?

\section{Method}

\section{Research Model}

This study was constructed to shed light on the usage of social media for educational purposes and was based on a survey model. It was designed as an exploratory research of knowledge levels, practices, and educational researchers' opinions regarding the use of social media within educational studies in Turkey. Exploratory research is carried out to describe situations that have not been sufficiently experienced or examined before. This kind of research provides some data for further studies. In exploratory researches, the question of what is more important than the reasons (Reiter, 2017). The data were collected via an online survey which was developed by the author. The survey info was sent via e-mail to over a thousand Turkish educational researchers whom info was found on universities' websites. Three reminder e-mails were sent to who not completed the survey following the first message after every forty-five days. Before the data analysis, the online survey was available for six months and participants had as much time as they needed to complete the survey. They could access the online survey how many times they want and save it to continue in another day but only submit it once.

\section{Data Collection Tool}

The items developed for the survey were prepared having completed a thorough literature review on research, educational researches and studies, Web 2.0 technologies, social media tools, and utilizing from them in learning and teaching activities in formal and informal learning. After review, focus group interview was conducted with 5 scholars from different disciplines at the faculty of education to determine survey questions. For survey validity, expert opinions were attained to see if the questions were appropriate in measuring the intended research questions and if the statements were understandable. Based on the feedback received from the experts, the survey was modified. At the development stage, literature review, focus group interview and expert review steps were used. The survey consisted of four sections with 25 questions and four of them were open-ended. In the first section, 
demographic characteristics of educational researchers such as university, department, title, gender, age, and experience in educational research were collected through six questions. The results were compiled and reported in participants section.

The second section was contained 13 Likert type questions to elicit the state of researchers' knowledge, using, and utilizing levels of information and communication tools, the Internet, Web 2.0, and social media. This section's questions are; What is your skill level in information and communication technologies? Are you familiar with Web 2.0 technologies? Do you comment on the content on social media? Do you know the difference between Micro Blog and Macro Blog applications? Do you follow the forums? Do you share on video sharing sites (Youtube, izlesene, etc.)? and like these.

Part III consisted of two items that focused on the state of utilizing from social media of educational researchers in past and future educational researches. The questions were; Did you use social media in your educational research? and Do you consider using social media in your educational research in the future? Response choices were "No, I didn't use, I used social networks, I used video sharing sites, I used photo sharing sites, I used forums, I used instant messaging systems, I used other social media items" and future forms. Participants could choice multiple. In the fourth section with four open-ended questions, educational researchers' opinions on the using social media in educational researches were gathered for the last research question. The open-ended questions focus on social media strategies in educational researches, especially research design and methods.

\section{Participants}

The data reported in this article were collected as part of a larger educational researchers sampling. Requests for participation in the study were emailed to the over a thousand educational researchers in Turkey. Because the primary objective of the research is to examine the using of social media within educational researches, especially connected with educational researchers. A total of 207 educational researchers (120 females (58\%) and 87 males (42\%)) from 59 public and private universities across Turkey voluntarily completed the survey. Ages and experiences of participants varied significantly. The mean age was 32 (range $=22-64$ ) and the mean duration of experience in educational researches was 7 years (range $=1-28)$. They were from various 6 departments at 59 universities. Departments are Computer and Instruction Technology Education (CITE), Primary Education, Secondary Education, Mathematics Education, Science Education, and Educational Sciences from faculties of education and educational sciences. The participants consisted of 9 professors (5\%), 11 associate professors $(5 \%)$, 39 assistant professors (19\%), 77 research assistants and lecturers (37\%), and 71 graduate and Ph.D. students $(34 \%)$. Only 2 researchers $(1 \%)$ reported they did not have enough knowledge about using information and communication technologies. While 41 researchers (20\%) were feeling themselves a little competent, 164 researchers $(79 \%)$ stated they had enough knowledge and skill. All educational researchers participated in this study, use the Internet as a research environment. Then, the aim of using the Internet later than using as research environment is the style of utilizing from communication services $(n=202,98 \%)$. The rates of using the Internet of researchers as a learning environment $(\mathrm{n}=160,77 \%)$, watching videos and listening to music $(\mathrm{n}=159,77 \%)$, and bank processes $(n=164,79 \%)$ are almost the same.

\section{Statistical Analysis}

The Statistical Package for the Social Sciences (SPSS) for Windows version 24.0 and Microsoft Office Excel 2016 were used to conduct the chi-square analysis and determine the frequencies and percentages. Descriptive statistics and chi-square test for one sample were used to summarize and present the quantitative data from the survey. To investigate whether levels of social media usage differ significantly in researchers' gender, age, experience, and department, chi-square test for one sample was performed. Additionally, qualitative data from the open-ended survey questions were analyzed by content analysis method to provide more in-depth information on educational researchers' opinions. Given that there is relatively limited research on research strategies of using social media in education, qualitative methods were used to explore the research questions through rich descriptions and explanations. The responses to open-ended questions were evaluated by the researcher and an expert in this field who uninformed about questions of this research, together. All qualitative data were reviewed multiple times. After the categories had been formed, the data were coded in terms of categories, again. Analysis basing on these codes was conducted. Krippendorff's Alpha was calculated for the reliability of content analysis and the Krippendorff's Alpha coefficient was found .879. 


\section{Findings}

\section{The Knowledge and Use Levels of Educational Researchers About Social Media and Web 2.0 Technologies}

The structure supplying the development of social media on the Internet is Web 2.0 technology. According to the analysis results (Table 1), although the 142 of educational researchers $(69 \%)$ have knowledge about social media, only 60 researchers (30\%) stated that they know Web 2.0 technologies. While 2 researchers (1\%) do not know anything about social media, 88 researchers (43\%) do not have any knowledge of Web 2.0 technologies. Besides, 167 researchers $(81 \%)$ do not know the difference between micro and macro blogs. It has been presented that educational researchers do not know how social technologies are named. In fact, they know what Twitter or BlogSpot is. But they do not know the differences between them which one is a micro or a macro blog. However, it can be said that the knowledge level of educational researchers about Web 2.0 and social media is fairly high level. Only they need a bit technical support about this issue.

Table 1. The Knowledge Levels of Educational Researchers on Social Media and Web 2.0 Technologies

\begin{tabular}{lcclcc}
\hline \multicolumn{2}{c}{ Social Media Knowledge Level } & \multicolumn{3}{c}{ Web 2.0 Knowledge Level } \\
\hline & $\mathrm{f}$ & $\%$ & $\mathrm{f}$ & $\%$ \\
\hline I have enough information & 142 & 69 & I have enough information & 60 & 29 \\
I know partially & 63 & 30 & I know partially & 59 & 28 \\
No information & 2 & 1 & No information & 88 & 43 \\
\hline
\end{tabular}

Most of the educational researchers $(\mathrm{n}=177,86 \%)$ have membership on a social networking system (SNS). When the participation state to social media is examined (Table 2), it has been seen that only 42 researchers (20\%) write comments on sharing documents on social media. While 64 researchers (31\%) never write a comment, 101 researchers $(49 \%)$ do sometimes. Also, most of the researchers $(n=126,61 \%)$ do not have a blog page and do not follow a blog belonging to others $(n=108,52 \%)$. Researchers have tendency of following forums $(n=130,63 \%)$ and using instant messaging programs $(\mathrm{n}=172,83 \%)$. They do not prefer sharing video or photographs on social media. Educational researchers are accustomed to using forums and instant messaging programs in daily life. To become a member of SNS stems from their popularity. But educational researchers do not use social media effectively. In order to benefit from social media features in educational studies, educational researchers must be aware of the benefits of social media and they should use all social media tools in their lives. They have a need for guidance on this issue. Computer and information technologies educators, educational technologists or instructional designers may help them.

Table 2. Social Media Usage Rates of Educational Researchers

\begin{tabular}{lcccc}
\hline & \multicolumn{2}{c}{ Yes } & No \\
\hline Have a... & $\mathrm{n}$ & $\%$ & $\mathrm{n}$ & $\%$ \\
\hline ...social network membership & 177 & 86 & 30 & 14 \\
...blog page & 81 & 39 & 126 & 61 \\
...followed blog belonging to others & 99 & 48 & 108 & 52 \\
...followed forum & 130 & 63 & 77 & 37 \\
...instant messaging system account & 172 & 83 & 35 & 17 \\
...shared video on video sharing sites & 25 & 12 & 182 & 88 \\
...shared photo on photo sharing sites & 19 & 9 & 188 & 91 \\
\hline
\end{tabular}

Most of the educational researchers $(n=129,62 \%)$ stated that they used social media in their previous educational studies (Table 3). 78 researchers (38\%) did not use social media in their previous researches and 18 of them $(23 \%)$ do not think to use social media in their future educational studies. Only 3 of the researchers $(2 \%)$ used social media within their previous researches but do not think to use it in their future studies, again. So, researchers who used social media within their previous researches plan using it within their future studies again and most of the researchers who did not use social media within their previous researches think to use it for their future studies. Basing on this finding, it can be said that social media will be used more intensely in educational studies. The field experts have a great responsibility for the correct use. It has been seen that educational researchers utilized $(n=86,42 \%)$ and will utilize $(n=156,75 \%)$ from SNS in their educational studies mostly. The 
other popular social media and Web 2.0 tools are forums, blogs, and instant messaging systems. At this point, it can easily be said that educational researchers more utilize from social media elements which they know well and use in their daily lives.

Table 3. The State of Social Media Utilization of Educational Researchers

\begin{tabular}{|c|c|c|c|c|c|}
\hline \multicolumn{3}{|c|}{$\begin{array}{c}\text { The Rate of Using Social Media of Researchers in } \\
\text { Their Previous Studies }\end{array}$} & \multicolumn{3}{|c|}{$\begin{array}{c}\text { The Rate of Using Social Media of Researchers' } \\
\text { Thought for Future Studies }\end{array}$} \\
\hline & $\mathrm{n}$ & $\%$ & & $\mathrm{n}$ & $\%$ \\
\hline No, I have not used. & 78 & 38 & No, I do not think. & 21 & 10 \\
\hline I have used social networking sites. & 86 & 42 & I may use social networking sites. & 156 & 75 \\
\hline I have used blogs. & 58 & 28 & I may use blogs. & 103 & 50 \\
\hline I have used video sharing websites. & 45 & 22 & I may use video sharing websites. & 88 & 43 \\
\hline I have used photograph sharing websites. & 24 & 12 & $\begin{array}{l}\text { I may use photograph sharing } \\
\text { websites. }\end{array}$ & 57 & 28 \\
\hline I have used forums. & 63 & 30 & I may use forums. & 115 & 56 \\
\hline I have used instant messaging systems. & 71 & 34 & I may use instant messaging systems. & 112 & 54 \\
\hline I have used other social media elements. & 43 & 21 & $\begin{array}{l}\text { I may use other social media } \\
\text { elements. }\end{array}$ & 74 & 36 \\
\hline
\end{tabular}

\section{The Relation Between Demographic Characters and Using Social Media}

In this study, a significant relationship between the gender, categorized age (20-29, 30-39, 40 and over), categorized research experiences $(1-5,6-10,11-15,15$ and over) and the knowledge level of educational researchers about social media, Web 2.0 technologies and blog has not been indicated. That means all educational researchers in the same departments have same knowledge level about social media, Web 2.0, and blogs.

A significance relation between researchers' departments and knowledge level about Web 2.0 technologies

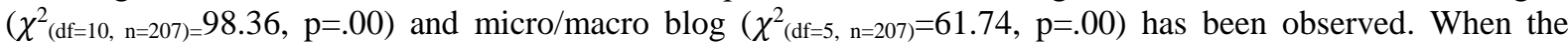
relation about the knowledge level of Web 2.0 technologies and blogs emerged from differences among departments has been examined, it has been seen that researchers studying at the department of CITE have more knowledge than other researchers study at the other departments. A similar situation has occured in following

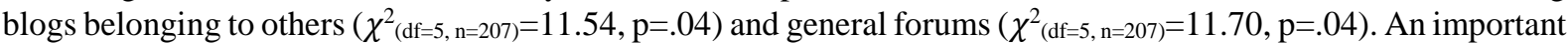
difference has been seen also in these behaviours. The main reason for this as CITE is more technical department than others in faculties of education in Turkey.

The participants, over 40 ages and having 15 years and over experience duration, utilize from social media within educational studies less and think to utilize less. The relation has been found significance statistically

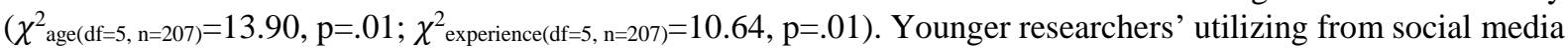
more than others can arise from their adapting to social media and using more intensely.

The ability of to use information and communication technologies has not created any effect on using social media within educational researches. It can be said that this state arises from the easiness of using social media and needlessness of upper technological abilities.

It has been seen that using social media in upper level (knowing properties of blogs $\left(\chi^{2}(\mathrm{df}=1, \mathrm{n}=207)=4.87, \mathrm{p}=.03\right)$,

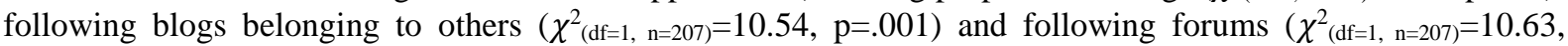
$\mathrm{p}=.001)$ ) has a significance relation with usage of social media items within educational studies. This finding can be commented so, educational researchers using social media in details want to use these detailed features in their educational studies.

The participants from the CITE department utilizes from social media more than others $\left(\chi_{(\mathrm{df}=5, \mathrm{n}=207)}^{2}=13.90\right.$, $\mathrm{p}=.016)$. The rate of using blogs $\left(\chi^{2}(\mathrm{df}=1, \mathrm{n}=207)=18.74, \mathrm{p}=.002\right)$ and forums $\left(\chi^{2}(\mathrm{df}=1, \mathrm{n}=207)=13.83, \mathrm{p}=.017\right)$ of CITE researchers are quite higher than other department researchers. This finding is in accordance with the finding that researchers study at the department of CITE use blogs and forums more active and using social media in details and they want to use these detailed features in their studies. This outcome points out that the state of utilizing from social media within educational studies is related not only to educational researchers' using social media but also related with their recognizing the power of social media. 


\section{Opinions About Usage of Social Media Within Educational Studies}

The opinions of the researchers about using social media within educational studies are given in Table 4. Most of the researches think positive about using social media within educational studies.

ER10: "I am currently using an elective course in topics such as giving instructions, sharing products, doing research. According to age groups, various restrictions should be introduced."

ER61: "I follow closely because of my work areas. When I attend a computer course, I am giving hands-on training to teacher candidates. Our age is an era in which technology and informatics have become indispensable in our lives, so I find it useful for teachers and students to use it. Even young children spend hours on the internet with their Facebook memberships, and I think it might be more interesting for them to use social networks for educational purposes."

Table 4. The Researchers' Opinions About Being Used of Social Media within Educational Studies

\begin{tabular}{lcc}
\hline Opinions About Using Social Media & $\mathrm{f}$ & $\%$ \\
\hline Very important, it must be used & 19 & 9 \\
I have been using and will continue to use in the future & 8 & 4 \\
It can be used & 154 & 74 \\
I do not use, I may use within future & 8 & 4 \\
I do not use, I do not think to use within future & 10 & 5 \\
I see useless & 8 & 4 \\
\hline
\end{tabular}

Only 18 participants stated that they did not use social media in their educational studies and do not intend to use them. They stated that they do not need social media or they do not have enough preparation for the studies in this environment.

ER82: "I have not done any studies on the social networks because of my department."

ER115: "For now, I am not using since not prepared enough material for sharing."

ER194: "I didn't have the opportunity to study the works of social media. Frankly, I've never met before. I don't know how I can use social media."

The participant views of the contributions and limitations of social media within educational studies are also presented in Table 5.

Table 5. The Views on the Contributions and Limitations of Social Media in Educational Studies

\begin{tabular}{lcclcc}
\multicolumn{1}{c}{ Contributions } & $\mathrm{f}$ & $\%$ & \multicolumn{1}{c}{ Limitations } & $\mathrm{f}$ & $\%$ \\
\hline Access to wide mass and data & 45 & 29 & Reliability & 32 & 64 \\
Actuality & 36 & 23 & Lack of literature & 7 & 14 \\
Effectiveness & 31 & 20 & Appropriateness for a specific & 3 & 6 \\
& & & audience and content & \\
Participation & 26 & 17 & & \\
Easiness of application & 16 & 10 & & \\
\hline
\end{tabular}

According to the participants, accessing to wide mass and data $(\mathrm{f}=45,29 \%)$ is the most advantaged character of social media.

ER2: "I think it should be used, it is saving time in educational research. For an educator, time is one of the most important elements to pay attention to. Economically, many people can be reached without any cost."

ER22: "I think it should definitely be used to reach more data."

ER44: "I think that social media can be used in educational research by considering the huge increase in the number of users in the past 1-2 years and the dependence of young people on these sites."

ER85: "Social media can be used for education since its popularity and ability to easily reach wide mass."

Researchers mentioned the actuality $(\mathrm{f}=36,23 \%)$, effectiveness $(\mathrm{f}=31,20 \%)$, participation $(\mathrm{f}=26,17 \%)$ and easiness of application $(\mathrm{f}=16,10 \%)$ as the other positive characters of social media. 
ER13: "As day by day, the place of social media in our lives is increasing. So much so that now we are not only when we are at the computer, but almost every moment we have become on social media. In my opinion, it is unthinkable that applications that have such profound impact on our daily lives are not used in educational studies."

ER15: "People who have been freed from a formal structure often share their thoughts more easily with each other on social media. I also think that it should be used in educational research when considering the power and impact of social media."

ER18: "I think it might be useful. Because I continue to use it because its effectiveness in my lessons."

ER20: "I use blogging in my lessons. Sharing the course documents is very useful in terms of the discussions about the course."

ER24: "I think it should be used because I believe that the social media is up to date and wide on sharing. As a result, actuality is important for educational researches, even in all kinds of research."

ER27: "Especially, I think that it is a social environment for internet-supported education, it is easy to use and it stands out with its features of expressing itself freely; and the fact that a large part of the current generation is used is also an important reason."

ER55: "I think social media environments are used by most of the students. So, these environments can be used in educational research. I am using blog, video sharing and social media in my researches and I am very satisfied. Because students know the environments, they can focus on the activities they will do rather than the use of these technologies."

ER121: "Our students have changed and they live in a digital life. We need to get to know them well in order to give them 21st century skills. In this sense, social media offers educators a favourable environment."

ER130: "We see that social media is used in most of the recent educational researches. Considering that university students are now digital native, I think this is a necessity rather than a choice. Since the basis of education is human and communication is the basic in the interaction of people, it is extremely common to use the means of communication that the age requires."

The most intense negative view about social media's being used within educational studies of researchers is that social media is an unsafe environment $(\mathrm{f}=32,64 \%)$.

ER6: "I don't find it reliable enough."

ER42: "I think it's harder to maintain reliability."

ER57: "I think it's difficult to maintain reliability in the process of use. Detailed information on the areas to be used is required. The user must have a high level of competence."

ER108: "It sounds to me that social media is virtual media."

ER201: "I think there are concerns about its reliability."

Besides, lack of background $(\mathrm{f}=7,14 \%)$ and appropriateness to a certain mass and content $(\mathrm{f}=3,6 \%)$ are regarded as other negative states.

ER23: "I do not think that sufficient theoretical and practical studies have been carried out to ensure the effective use of social media in educational studies."

ER32: "Social media supports education. But I don't think social media is appropriate for every application. I do not think that there is yet a consensus on social media and research methodology. According to the type, sample and subject of the study, this difference should be determined by the researcher. Personally, I do not think that both qualitative and quantitative information will be taken / received correctly. I think it's right to develop a new discourse about getting and analysing information from social media."

ER38: "It only addresses people who use the Internet and social media."

ER116: "Today, the relationship between social media and education is a huge problem for us. The theoretical foundations of the literature cannot be clearly defined." 
The researchers' opinions about the structure of an educational research, social media will be used, have been presented in Table 6.

Table 6. Opinions About the Data Gathering Method and Research Design for The Educational Researches Social Media Will Be Used

\begin{tabular}{|c|c|c|c|c|c|}
\hline \multicolumn{3}{|c|}{ Preferred data gathering method } & \multicolumn{3}{|c|}{ Points paid attention in preferring the data gathering method } \\
\hline & $\mathrm{f}$ & $\%$ & & $\mathrm{f}$ & $\%$ \\
\hline Mix & 82 & 42 & Integrant of qualitative and quantitative & 49 & 27 \\
\hline Only qualitative & 37 & 19 & Reliability & 38 & 21 \\
\hline Only quantitative & 37 & 19 & $\begin{array}{l}\text { It is indicated according to research } \\
\text { question }\end{array}$ & 38 & 21 \\
\hline \multirow[t]{5}{*}{$\begin{array}{l}\text { All of them can be used } \\
\text { separately }\end{array}$} & 41 & 20 & $\begin{array}{l}\text { The appropriateness of social media for } \\
\text { only qualitative design }\end{array}$ & 18 & 10 \\
\hline & & & The effort of accessing to more data & 14 & 8 \\
\hline & & & Application fast & 11 & 6 \\
\hline & & & $\begin{array}{l}\text { The appropriateness of social media for } \\
\text { only quantitative design }\end{array}$ & 7 & 4 \\
\hline & & & $\begin{array}{l}\text { The appropriateness of social media for } \\
\text { all research design }\end{array}$ & 6 & 3 \\
\hline \multicolumn{3}{|c|}{ Preferred research design } & \multicolumn{3}{|c|}{ Points paid attention in designing research } \\
\hline & $\mathrm{f}$ & $\%$ & & $\mathrm{f}$ & $\%$ \\
\hline Experimental model & 96 & 59 & Reliability & 58 & 45 \\
\hline Survey model & 31 & 19 & Research question & 36 & 28 \\
\hline \multirow[t]{2}{*}{ Mix model } & 35 & 22 & Originality & 13 & 10 \\
\hline & & & Easiness of application & 13 & 10 \\
\hline
\end{tabular}

When the findings are examined, it has been seen that educational researchers prefer mix method $(\mathrm{f}=82,42 \%)$ within the experimental model $(\mathrm{f}=96,59 \%)$ for the researches which social media will be used.

ER1: "If we want to be effective in the work that will take place on social media, experimental designs like fictional research order are my choice."

ER11: "I prefer the experimental model. The reason is that analysis of the data collected via a pre-arranged system is easier than analysing the data obtained from a randomly prepared medium."

ER13: "I think that social media is suitable for both qualitative and quantitative research. Therefore, the mixed data collection method is quite appropriate. The model to be used may vary depending on the type of research, but I think that a structured research can provide results that will facilitate the study to reach its goal. Therefore, I give priority to experimental design."

ER20: "I prefer mixed method. To compare the results obtained from two research methods, to investigate the research sub-problems in depth."

ER23: "Mixed. Because I believe that reliable results cannot be achieved with only quantitative or qualitative data. I think selecting an experimental model can be more effective in achieving the desired results."

ER26: "I prefer experimental research. Because it is very important that learners are guided in the teaching process. Otherwise, it may be difficult for us to reach our goal."

ER44: "I prefer experimental because originality is an important element in educational research."

According to the educational researchers, the important points paid attention in preferring the data gathering method are integrant of qualitative and quantitative $(\mathrm{f}=49,27 \%)$, reliability $(\mathrm{f}=38,21 \%)$, and research question $(\mathrm{f}=38,21 \%)$.

ER5: "It becomes quantitative. If we want to get a little more explanatory information qualitatively, we should be able to ask questions."

ER16: "A superficial and general information can be obtained by conducting a questionnaire study and deeper and more specific information can be obtained through interviews. Thus, integrity is ensured." 
ER39: "I prefer the method where I can find the best answer to my research question because the Qualitative, Quantitative and Mixed methods have different properties and are related to different situations."

ER46: "I prefer mixed data collection. Because I believe that only qualitative or quantitative studies are not sufficient in terms of revealing situations. I think that the results obtained with quantitative data will increase the reliability of the data obtained by supporting qualitative interviews and observations."

ER57: "I prefer qualitative or mixed method. My preferred reasons are to gain in-depth data, to increase reliability by using different data sources and data collection tools, and to provide more comprehensive information about people's experiences and perceptions."

ER63: "I think I prefer mixed method. Qualitative data and quantitative data will need to be combined."

ER88: "Mixed. Because I prefer to see whether the qualitative and quantitative findings support each other."

ER184: "It depends on the subject and the data of the research."

At the same time, participants stated that reliability $(\mathrm{f}=58,45 \%)$, research question $(\mathrm{f}=36,28 \%)$, originality $(\mathrm{f}=13,10 \%)$, and easiness of application $(\mathrm{f}=13,10 \%)$ are important factors for research design to utilize from social media within educational researches.

ER38: "The designs will vary according to the purpose and method of research."

ER41: "It depends on my research question. I'd prefer whichever is more appropriate."

ER145: "The same approaches should be used in studies carried out by social media if educational scientists are using normal conditions because it is important to ensure the reliability of the research."

ER187: "It should definitely be used, but data must be true"

\section{Discussion, Conclusions, and Suggestions}

It has been found that all the participating educational researchers use the Internet as a research environment. It is very normal because of the Internet's features. Frankel and Siang (1999) also state that the Internet contributes to the growing pool of knowledge and grants researcher potential access to a geographically and culturally diverse population. Therefore, educational researchers like to utilize from the Internet for their researches. However, there is not enough empirical study for the professional use of social media as educational environment (Popa and Voinea, 2017). According to Grosseck and Holotescu (2011), a popular social media topic for researchers is the use of microblogging in academic research. Similarly, Sullivan (2017) expresses that scholars utilize from Google Scholar, RSS and Pinterest to find research and teaching materials. It has been seen that educational researchers use the Internet for daily and professional lives such as communication, teaching and entertainment systems. For these activities, Web 2.0 tools and social media are very important which offered via the Internet. Chen and Bryer (2012) also found that their interviewees used social media, either for personal, academic, research, or professional purposes. Similarly, Cao et al. (2013) and Veletsianos (2013) state that college faculty members and higher education scholars use social media applications for personal and professional lives. Gülbahar et al. (2017) found that higher education instructors from Germany, Russia, Switzerland, and Turkey actively use social media for private purposes. Manca and Ranieri (2016) state that personal use is almost always associated with professional use. Similarly, in this study, it has been seen that researchers who benefit from social media in their daily life more benefit from these detail features in their educational studies.

Although Web 2.0 and social media are part of the Net, all Internet users do not use them. For example, while all participants use the Internet in this study, $69 \%$ of them have knowledge about social media and only $30 \%$ know Web 2.0 technologies. Though social media and Web 2.0 is very popular in our lives, it has been seen that 2 researchers $(1 \%)$ do not know anything about social media and 88 researchers (43\%) do not have any knowledge about Web 2.0 technologies. Chen and Bryer (2012) stated that according to a survey $80 \%$ of the 4,600 faculty members from 50 U.S. colleges and universities did not know or never used social media technologies such as blogs, wikis, Google docs, video conferencing, video games, or virtual worlds, in 2009. In 2010, another survey relevant to this issue points out that $61 \%$ of teachers, principals, and librarians are active in at least one social media space. Many use those spaces for professional development-attending webinars, watching YouTube videos, listening to podcasts, or participating in blogs (edWeb.net 2010: as cited in Ferriter, 2010-2011). 
Chu and colleagues (2017) state that there is little need for technological knowledge for the effective use of social networking applications and sites. In this study, it has been seen that the level of information technology skills of the participants does not make any difference between the social media usage. Because social media elements are easy to use and do not require high level information technology skills, academicians have a high percentage of membership in social media (Chu et al., 2017). However, educational researchers do not use social media effectively. For example, in this study, most of the Turkish educational researchers $(n=177,86 \%)$ have a membership of an SNS. But only 42 researchers $(20 \%)$ write the comment on social media. While 64 researchers (31\%) state that they never write a comment, 101 researchers (49\%) say that they sometimes write the comment. At the same time, most of the researchers $(\mathrm{n}=126,61 \%)$ do not have a blog page and do not follow a blog belonging to others $(\mathrm{n}=108,52 \%)$. Researchers have a tendency of following forums $(\mathrm{n}=130,63 \%)$ and using instant messaging programs $(n=172,83 \%)$ and they do not prefer sharing video or photographs on video or photograph sharing websites. Similarly, it had been seen that educators in higher education in Turkey are not effective social media users although they have membership in Çelik and friends' (2014) study.

According to Cao et al. (2013) educators use social media applications in class sessions. Different social environments (eg Facebook, Flickr, PBworks, Twiter, WordPress, YouTube) offer educators and students special tools for in-out classroom activities (Dabbagh \& Kitsantas, 2012). Gao, Luo, and Zhang (2012) and Veletsianos (2013) also state that blogs and other social media tools could help to faculty in their teaching activities because they have great potential of promoting learning. In this exploratory research, it has been seen that $62 \%$ of the researchers utilized from social media for their previous studies and $90 \%$ of them think to utilize from social media for their future studies. Albion (2008) states the importance of using technologies like social media within an educational environment and it is not in question to exclude educators from the development process.

While educators use social media in the learning and teaching process, they would prefer different ways (Cao et al., 2013). For example, some scholars in China prefer to find teaching materials (Sullivan, 2017). In this study, educational researchers stated that they especially preferred SNS $(41.55 \%)$ and they might use them in future studies (75\%). Similarly, Çelik et al. (2014) found that academicians were using social networks mostly. SNS's features are very appropriate for activities in formal and informal learning (Grosseck \& Holotescu, 2011; Mazman \& Koçak-Usluel, 2010; Veletsianos et al., 2013). So, it is used extensively by educators (P. Amador \& J. Amador, 2014; Grosseck \& Holotescu, 2011; Sanchez, Cortijo \& Javed, 2014; Sarapin \& Morris, 2015).

The main problem with the use of social media in educational studies is the lack of knowledge and skills about how to integrate effectively from an instructional design perspective (Donelan, 2016; Gülbahar et al., 2017; Neier \& Zayer, 2015; Rochez, 2015). As a result of the studies conducted, it is mentioned that social media can be used for educational purposes (Borštnar, 2012; Wang, 2012). But many instructors are unsure how to use social media in educational settings (Gülbahar et al., 2017). A Pearson report indicates that $88 \%$ of American faculty members use institutional and user-generated videos that they have found online, through recommendation, or using online rating and comments (Moran et al. 2012: as cited in Cao et al., 2013). There is no model or design on using social media for educational purposes. In this study, educational researches have complained about the insufficiency of literature. Similarly, Ajjan and Harsthone (2008) have also stated that there are so limited researches and analysis about the usage of social media and Web 2.0 means within educational environments. Researches cannot be conducted since the real potential of the Internet and social media in terms of social sciences has not been recognized (Wilkinson \& Thelwall, 2011). So, by focusing on using social media in future educational researches, useful using styles should be formed. Higher education instructors need this support to overcome possible barriers for effective use of social media in education (Gülbahar et al., 2017; Neier \& Zayer, 2015; Rochez, 2015; Smith, 2016).

It has been seen that researchers studying in the department of CITE use social media more effective, and younger ones utilize from social media more and think to utilize more. Similarly, it is stated that the young generation started this information travel as digital natives have higher experience and older educators have problems about this matter (Hanson et al., 2011; Wankel, 2009). In this study, it has been found that if educational researchers use social media in details, they want to use these detailed features in their educational studies. According to Dahlstrom (2012: as cited in Cao et al., 2013), faculty members adopt social media differently and their adoption varies by age. The younger they are, the more likely they tend to adopt social media tools. Some studies (Manca \& Ranieri, 2016; 2017) also show that discipline and age are important factors to utilize social media in education for scholars. 
Various uses of social media within education like sharing, social support, and increasing opportunities are mentioned in the literature (McLoughlin \& Lee, 2007; Muijs, West, \& Ainscow, 2012). Within this study, researchers said that accessing to wide mass, the compliance with the present, effectiveness, contributing and easiness of application are the most important advantages of using social media within educational studies. Appropriateness to a certain mass and content, lack of background, and being an unsafe environment of social media have been stated as the negative characters. One of the most important matters in researches in which social media will be used as a research environment is designing the research. Although online research models are qualified as having important opportunities in terms of social sciences research, these research models have not been explained adequately in the literature (Hookway, 2008). Generally, it is stated that qualitative and quantitative researches can be conducted with various methods in terms of gathering data via the Internet (Hookway, 2008; Wilkinson \& Thelwall, 2011). In different areas, Eysenbach and Till (2001) stated that Internet postings are accessible for qualitative research in health discipline and Back (2013) also pointed out that with gained trust, triangulation of data, and consistent observation, Facebook interactions offer an important addition to research on study abroad. In the present study, it has been found that educational researchers prefer mix methods in data gathering for the educational researches social media will be used. Researchers also stated that research question and reliability are important. Educational researchers expressed that they have the tendency of using experimental model for an educational research will be conducted by using social media. Originality and easiness of application are the other matters to be paid attention primarily.

\section{Conclusions}

- Educational researchers have general knowledge about Web 2.0 and social media. However, they do not know much about the technical aspect of social media.

- Despite the lack of a theoretical literature for the use of social media in educational studies, educational researchers plan to use social media in their future studies.

- The most of education researchers have social media membership. However, they do not participate effectively on social media. They generally tend to follow forums and use instant messaging systems.

- Social networks are mostly used in educational studies. Forums and instant messaging systems are the other most used social media elements.

- Educational researchers tend to benefit from social media elements in educational studies that they know well and use in their daily lives more. Educational researchers who use social media more effectively also think about using social media more intensively in their educational studies.

- The ability of using information and communication technologies has no impact on the use of social media in educational research.

- Educational researchers from the same department have equal knowledge on social media, Web 2.0 and blogs. Among the departments, CITE academicians have the most information and use tendency.

- Young education researchers are more enthusiastic about using social media in educational studies.

- The contributions of social media to education studies include access to wide mass and data, being actual and effective, enabling participation, and ease of using.

- In terms of the limitations of the use of social media in education, it is stated that reliability, lack of literature, and appropriateness for a specific audience and content.

- Educational researchers prefer experimental design as a research model for social media using. They pay attention to reliability and research question in terms of research design. They prefer mix method for data collection. Due to the qualitative and quantitative complementing each other.

\section{Suggestions}

- Educational researchers want to use social media in their educational studies. Researchers often tend to benefit more from the social media elements they know and use well. Some information seminars, on the integration of social media with technical aspects and correct use, can be organized by the field experts in universities. 
- Education researchers generally do not draw an effective profile on social media. Nevertheless, it was observed that researchers who use social media more intensively benefited from educational research. Therefore, educational researchers should be encouraged to adopt and evaluate social media technologies for teaching because such use enhances student satisfaction and learning outcomes as cited in Cao et al., (2013), Chen and Bryer (2012), and Gao et al. (2012).

- After this exploratory research, detailed researches can be conducted in other types. Thus, various examples of different uses of social media as a research or teaching environment can be presented to educators (Chen \& Bryer, 2012; Veletsianos et al., 2013). At the same time, the ground can be prepared for model studies on the use of social media in educational studies within Turkish culture.

- Yoo and Huang (2011) stated that cultural difference can influence how students accept technology and how this different use can affect learning. These changes can help educators to integrate appropriate Web 2.0 tools into educational environments efficiently. Similarly, Donelan (2016) states that culture has an impact on the use of information technologies and social media. Therefore, it is advisable to consider cultural differences in future studies. 
Çalışkan, E. (2019). How Do Educational Researchers Utilize from Social Media? Bartın University Journal of Faculty of Education, 8(1), 179-207.

\section{Eğitim Araştırmacıları Sosyal Medyadan Nasıl Yararlanmaktadır? Giriş}

Web 2.0, 2004 yılında web tabanlı hizmet ve uygulamaların ikinci kuşağı olarak tanımlanmıştır (Poynter, 2010). Web 2.0 ile birlikte bireylerin İnternet üzerinden sosyalleşme, iş birliği ve paylaşım etkinlikleri kolaylaşmıştır (Lamb ve Johnson, 2007). Web 2.0 teknolojileri sayesinde, İnternet kullanıcıları sohbet edebilir, olayları ve haberleri yorumlayabilir ve durağan web sayfalarını görüntülemek yerine fotoğraf ve video paylaşabilir konuma gelmiştir (Gonzales, Vodicka ve White, 2011). Bu eylemler, sosyal medyayı oluşturmaktadır. Sosyal medya, "Web 2.0'ın ideolojik ve teknolojik temelleri üzerine kurulan ve kullanıcı tarafindan oluşturulan içeriğin paylaşılmasına izin veren İnternet tabanlı bir uygulama grubu" olarak tanımlanmaktadır (Kaplan ve Haenlein, 2010: 61). Sosyal medya, insanların iş birliği yapması, ortaklık kurması ve bilişim teknolojileri yoluyla paylaşımlarda bulunması için farklı özellikler sunmaktadır. Sosyal medya etkileşimleri web tarayıcılarından akıllı telefon uygulamalarına kadar çeşitli şekillerde ortaya çıkabilir (Castro, 2012). Bağlantıları bire çok (e-posta, anlık mesajlaşma), bire bir (bloglar, web gönderileri) ya da çoktan çoğa (vikiler) iletişim biçimlerini içerebilir (Murthy, 2008; Poynter, 2010).

Sosyal medya kullanıcılar tarafindan en çok eğlence amaçlı kullanılmaktadır (Smith, Salaway ve Caruso, 2009). Öte yandan, eğitim uzmanları sosyal medyanın kapasitesini sınırsız görmekte (Tyson, 2010) ve eğitim amaçlı kullanılmasına yönelik olumlu tutum sergilemektedirler (Poellhuber ve Anderson, 2011; Wankel, 2009). Öğrenciler de sıradan sınıf etkinliklerinden sıkıldıkları için Web 2.0 ve sosyal medya teknolojilerinin derslerde kullanılmasını istemektedirler (Mazman ve Koçak-Usluel, 2010; Yoo ve Huang, 2011). Prensky (2001a; 2001b; 2005) tarafından "dijital yerliler" olarak adlandırılan bu yeni nesil öğrencilerin farklı beceri ve ilgi alanları vardır. Onlar için eğitim sistemlerinde yöntem ve ortam değişikliğine gidilmesi önerilmektedir (Moll ve Nielsen, 2017). Değişim sürecinde eğitimciler, sosyal medya hizmetlerinden ve ders konularına yönelik araçlarından daha fazla faydalanmaya başlamışlardır (Bozanta ve Mardikyan, 2017; Chen ve Bryer, 2012; Ferriter, 2010-2011; Yoo ve Huang, 2011). Gerçekleştirilen çalışmalarda sosyal medyanın öğrencilerin öğrenim deneyimlerini geliştirmek adına önemli firsatlar sağladığ1 görülmüştür (Borštnar, 2012; Bryant, 2006; McLoughlin ve Lee, 2007; Selwyn, 2007; Yoo ve Huang, 2011). Aspey (2011) ve Castro (2012) yaptıkları çalışmalarında öğrencilerin geleneksel derslerden ziyade çevrimiçi derslerde öğretim etkinliklerine daha kolay katılım sağladıklarını ve eğitimcilerin sosyal medyayı kendi öğretim süreçlerinde kullanmaktan memnun kaldıklarını bulmuşlardır. Back (2013) Facebook gibi bazı sosyal medya araçlarının yabancı dil öğrenenler için önemli bir rol oynadığını belirtmiştir. Benzer şekilde Meishar-Tal, Kurtz ve Pieterse (2012), öğrencilerin Facebook'ta öğrenmekten memnun olduklarını ve bu çevrimiçi çalışma gruplarını gelecekteki derslerde de kullanmaya devam etmek istediklerini ifade etmişlerdir. Sosyal medyanın tüm eğitim alanlarında sosyal öğrenme deneyimleri açısından yeni öğretim ortamları olduğu belirtilmektedir (Friesen ve Lowe, 2012; Veletsianos, Kimmons ve French, 2013). İç mimarlık (Güler, 2015), spor yönetimi (O'Boyle, 2014), pazarlama ve yönetim (Al-Bahrani, Patel ve Sheridan, 2015), sağlık ve tıp eğitimi (Galiatsatos, Porto-Carreiro, Hayashi, Zakaria ve Noel, 2016; Maloney, Moss ve Ilic, 2014; Roy, Taylor, Cheston, Flickinger ve Chisolm, 2016) ve diğerleri gibi farklı alanlarda eğitim amaçlı olarak sosyal medyanın kullanıldığı çalışmalara rastlamak mümkündür. Çalışmaların çoğu, yükseköğretimdeki eğitim süreçleri için sosyal medya kullanımının birçok avantajını ortaya koymaktadır (Ada, Stansfield ve Baxter, 2017; Chu, Capio, van Aalst ve Cheng, 2017; Gülbahar, Rapp, Kilis ve Sitnikova, 2017; Güler, 2015; Matzat ve Vrieling, 2016; Smith, 2016).

Sosyal medyanın eğitsel anlamda kullanıldığı birçok çalışma ile karşılaşılmasına karşın son dönemlerde alan yazında kuramsal araștırmalara gereksinim olduğundan bahsedilmektedir (Greenhow ve Lewin, 2016). Gülbahar ve arkadaşları (2017) ile Matzat ve Vrieling (2016)'ya göre sosyal medyanın öğretim etkinlikleriyle güçlü bir şekilde nasıl bütünleştireceği henüz tam olarak bilinememektedir. Her çalışma kendine özgü farklı şeyler denemektedir (Greenhow ve Lewin, 2016). Bundan dolayı sosyal medyanın eğitim ortamlarında nasıl kullanacağ konusu alanda karşılaşılan önemli sorunlardan birisidir (Gülbahar ve ark., 2017). Evans (2014) yükseköğretimde sosyal medya kullanımının başlangıç aşamasında olduğunu belirtmektedir. Değişen teknoloji ve yaşantı standartlarından dolayı sosyal medyanın öğretim süreçlerine ne zaman ve nasıl entegre edileceği üzerine çalışılması gerekmektedir (Conway, 2011). Bu çalışmalarda eğitimcinin rolü çok önemlidir (Callaghan ve Bower, 2012). Ertmer (2005)'in de belirttiği gibi eğitimcilerin kişisel ve pedagojik inançlarıyla motivasyonları eğitimde başarılı teknoloji entegrasyonu için temel faktörler arasında yer almaktadır. Eğitimcilerin sosyal medya kullanım durumlarına ilişkin olarak; Pimmer, Linxen ve Gröhbiel (2012) sağlık alanındaki eğitimcilerin sosyal medyayı eğitim ortamı gibi kullanmalarına yönelik bir keşif araştırması yürütmüşler, Çelik, Kaplan Akıllı ve Onuk (2014) akademisyenlerin sosyal medya algılarını ve sosyal medyanın eğitsel kullanım potansiyelini eğitimciler açısından incelemişler, Rochez (2015) eğitim tarihçilerinin dijital teknolojileri ve sosyal medya kullanımlarını incelemiş, Li 
ve Greenhow (2015) eğitim bilimcilerin sosyal medyadan nasıl yararlandıklarını araştırmışlar, Donelan (2016)'ın odak noktası, Bilim, Teknoloji, Mühendislik ve Matematik (STEM) üzerine çalışan akademisyenlerin sosyal medyayı nasıl kullandıkları üzerine olmuş, Knight ve Kaye (2016) akademisyenlerin ve öğrencilerin Twitter kullanımlarını akademik bağlamda karşılaştırmışlar ve Manca ile Ranieri (2016) ise yükseköğretimde görevli eğitimcilerin sosyal medyayı kişisel, öğretim ve mesleki amaçlar için nasıl kullandıklarına ilişkin durumları ortaya koymayı hedeflemişlerdir. Son zamanlarda da sosyal medyanın eğitsel kullanımına yönelik model geliştirme çalışmalarında hareketlenme görülmeye başlanmıştır (örneğin, Bozanta ve Mardikyan, 2017; Brech, Messer, Schee, Rauschnabel ve Ivens, 2017; Garcia ve Costa Silva 2017; Greenhow ve Lewin, 2016). Ancak hem model çalışmaları açısından hem de eğitimcilerin sosyal medyayı kullanım durumlarının incelenmesiyle ilgili hissedilen eksiklik henüz giderilememiştir (Kimmons ve Veletsianos, 2016; Li ve Greenhow, 2015; Manca ve Ranieri, 2017; Veletsianos ve Kimmons, 2016). Farklı alanlardaki eğitimcilerle yürütülen çalışmalarla birlikte salt eğitim araştırmacılarının öğretim süreci ve araştırma tasarımları için konuya ilişkin durumlarının çalışılması önem arz etmektedir (Evans, 2014). Bununla beraber eğitim araştırmacılarının sosyal medya kullanım düzeylerini, sosyal medyayı araştırma ve öğretim ortamı olarak kullanma eğilimlerini inceleyen yeterli çalışma bulunmamaktadır. Türkiye'de de sosyal medyadan bir eğitim ortamı olarak yararlanılması konusunda araştırma eksikliği olduğu ifade edilmektedir (Aydın, 2012; Çelik ve diğerleri, 2014). Ulusal çalışmalar kapsamında yapılan ender araştırmalardan birisi olan Çelik ve arkadaşlarının (2014) çalışmalarında da sadece eğitim araştırmacıları değil aynı zamanda mühendislik ve doğa bilimleri gibi alanlardan eğitimciler de araştırmaya dahil edilmiştir. Sosyal medyanın öğretim süreciyle bütünleştirilmesi konusundaki kuramsal ve deneysel eksikliğinin giderilmesinde en önemli sorumluluk pedagojik açıdan da konuya hâkim olan eğitim araştırmacılarına düşmektedir (Evans, 2014). Bu keşif araştırmasının temel amacı, eğitim araştırmacılarının sosyal medyayı günlük yaşamlarında ve eğitim çalışmalarındaki kullanım durumlarını belirlemek ve sosyal medyanın eğitim araştırmalarında kullanımına ilişkin araştırma tasarımına yönelik görüşlerini incelemektir. Böylelikle alan yazında belirtilen eksikliğin giderilmesiyle sonraki çalışmalara zemin oluşturmak hedeflenmiştir. Araştırma keşfedici türde gerçekleştirildiğinden dolayı daha çok ne ve nasıl soruları üzerine odaklanılmış olup aynı zamanda eğitim araştırmacılarının sosyal medya kullanımlarının cinsiyet, yaş, deneyim ve bölümleriyle ilişkileri de belirlenmeye çalışılmıştır. Bu çalışmada aşağıdaki beş soru ele alınmıştır:

(1) Eğitim araştırmacılarının Web 2.0 ve sosyal medya ile ilgili bilgi düzeyi nedir?

(2) Eğitim alanındaki akademisyenlerin sosyal medya kullanım eğilimleri nasıldır?

(3) Eğitim araştırmalarında sosyal medyadan yararlanılma durumu nedir?

(4) Araştırmacıların sosyal medya ile web teknolojilerine ilişkin bilgi ve kullanım düzeyleri cinsiyet, yaş, deneyim ve bölümlerine göre değişiklik göstermekte midir?

(5) Eğitim çalışmalarında sosyal medyanın kullanımına ilişkin araştırmacı görüşleri nelerdir?

Yöntem

\section{Araştırma Modeli}

Tarama modelinde yürütülen bu çalışma, eğitim araştırmacılarının konuya ilişkin bilgi düzeyleri, kullanım eğilimleri ile görüşlerinin ortaya konulması adına keşfedici araştırma olarak tasarlanmıştır. Keşfedici araştırmalar daha önce yeterince deneyimlenmemiş ya da incelenmemiş olan durumların betimlenmesi amacıyla yürütülürler. $\mathrm{Bu}$ tür araştırmalar, araştırmacıların deneyimlerini, fikirlerini ve becerilerini kullanmalarını sağlayarak daha sonraki çalışmalar için sağlam bir zemin oluşturur. Keşfedici araştırmalarda nedenlerden daha çok ne sorusu üzerine durulmaktadır (Reiter, 2017). Çalışma için gerekli veriler, yazar tarafindan geliştirilen çevrimiçi bir anket ile toplanmıştır. Görüşme isteği ve çevrimiçi anket bilgileri, üniversitelerin web sitelerinde erişim bilgileri bulunan binden fazla Türk eğitim araştırmacısına e-posta aracılığıyla iletilmiştir. İlk mesajı takip eden her kırk beş günde anketi tamamlamayan akademisyenlere üç adet hatırlatma e-postası gönderilmiştir. Veri analizine geçmeden önce çevrimiçi anket altı ay boyunca yayımda kalmıştır. Katılımcılara anketi tamamlamak için ihtiyaç duydukları kadar zaman sunulmuş ve isterlerse çevrimiçi ankete başka bir gün devam etmek için kaydetme olanağ sunulmuştur. Ancak, katılımcı kendine gönderilen davet üzerinden sadece bir kez gönderme işlemi yapabilmektedir.

\section{Veri Toplama Aracı}

Geliştirilen anket formu için eğitim araştırmaları ve çalışmaları, Web 2.0 teknolojileri, sosyal medya araçları ve ögrretim etkinliklerinde kullanımları üzerine alan yazın taraması gerçekleştirilmiştir. İnceleme sürecinden sonra 
anket sorularını belirlemek adına eğitim fakültesinde görevli farklı disiplinlerden beş akademisyen ile araştırmanın problem durumu üzerine bir odak grup görüşmesi gerçekleştirilmiştir. Anketin geçerliliği için, soruların istenen durumların ölçülmesine uygun olup olmadığ 1 ve ifadelerin anlaşılabilir olup olmadığı konusunda uzman görüşleri alınmıştır. Uzmanlar tarafından alınan geri bildirimlere dayanarak, anket üzerinde ufak bir düzenlemeye gidilmiş ve son hali verilmiştir. Alan yazın taraması, odak grup görüşmesi ile uzman gözden geçirme adımları kullanılarak geliştirilen ve beş araştırma sorusuna odaklanan anket formu dördü açık uçlu olmak üzere 25 soru içeren dört bölümden oluşmaktadır. İlk bölümde, üniversite, bölüm, unvan, cinsiyet, yaş ve eğitim araştırmalarındaki deneyimleri gibi araştırmacılarının demografik özellikleri altı soruyla toplanmıştır. Bu bölümle ilgili elde edilen veriler katılımcılar bölümünde sunulmuştur.

İkinci bölüm eğitim araştırmacılarının bilişim araçları, Web 2.0 ve sosyal medyaya ilişkin bilgi, kullanma ve yararlanma düzeylerine yönelik geliştirilmiştir. Bu bölüm; Bilgi ve iletişim teknolojileri beceri düzeyiniz nedir? Web 2.0 teknolojileri hakkında bilginiz var mı? Sosyal medyada yer alan içeriklere yorum yazar misınız? Mikro Blog ile Makro Blog uygulamalarının farkını biliyor musunuz? Forumları takip eder misiniz? Video paylaşım sitelerinde (Youtube, İzlesene vb.) paylaşımda bulunur musunuz? gibi Likert tipinde 13 soru içermektedir.

Bölüm III, eğitim araştırmacılarının geçmiş ve gelecekteki eğitim araştırmalarında sosyal medyadan yararlanma durumuna odaklanan iki maddeden oluşuyordu. Ĕgitim alanıyla ilgili araştırmalarınızda sosyal medyayı kullandınız mı? ve Gelecekte yapacă̆ınız ĕgitim alanıyla ilgili araştırmalarınızda sosyal medyayı kullanmayı düşünür müsünüz? sorularına; "Hayır kullanmadım/düşünmüyorum, Sosyal ă̆ları kullandım/kullanabilirim, Blogları kullandım/kullanabilirim, Video paylaşım sitelerini kullandım/kullanabilirim, Fotoğraf paylaşım sitelerini kullandım/kullanabilirim, Forumları kullandım/kullanabilirim, Anlık mesajlaşma sistemlerini kullandım/kullanabilirim, Diğer sosyal medya ögelerini kullandım/kullanabilirim" yanıtlarından bir ya da daha fazla işaretleme olanağı sunulmuştur. Dört açık uçlu sorudan oluşan dördüncü bölümde, eğitim araştırmacılarının son araştırma sorusu için eğitim araştırmalarında sosyal medyayı kullanma hakkındaki görüşleri toplanmıştır. Bu bölümdeki açık uçlu sorular eğitim araştırmalarında, özellikle araştırma tasarımı ve yöntemleri açısından sosyal medyanın nasıl kullanılabileceğine odaklanmaktadır.

\section{Katılımcilar}

Bu çalışmada toplanan veriler büyük bir evrenin eğitim araştırmacıları örnekleminden toplanmıştır. Çalışmaya katılım istekleri Türkiye'deki binden fazla eğitim araştırmacısına e-posta ile gönderilmiştir. Araştırmanın temel amacı eğitim araştırmalarında sosyal medya kullanımını incelemek olduğundan dolayı özellikle eğitim araştırmacılarına ulaşılmaya çalışılmıştır. Türkiye genelinde 59 kamu ve özel üniversiteden toplam 207 eğitim araştırmacısı (120 kadın (\%58) ve 87 erkek (\%42)) araştırmaya gönüllü olarak katılmıştır. Katılımcıların yaşları (ortalama yaş 32; dağılım = 22-64) ve deneyimleri (ortalama deneyim süresi 7 yıl; aralık = 1-28) geniş bir dağılım göstermiştir. Eğitim araştırmacıları eğitim ve eğitim bilimleri fakültelerinin altı farklı bölümünde görev yapmaktadırlar. Katılımcılar arasında 49 öğretim üyesi (\%29), 77 öğretim yardımcısı (\%37) ve 71 yüksek lisans ve doktora öğrencisi (\%34) bulunmaktadır. Katılımcılardan sadece ikisi (\%1) bilgi ve iletişim teknolojilerini kullanma konusunda yeterli bilgiye sahip olmadığını bildirmiştir. 41 eğitim araştırmacısı (\%20) bilişim teknolojileri konusunda kendilerini biraz yeterli hissederken, 164 araştırmacı (\%79) oldukça yeterli bilgi ve beceriye sahip olduklarını belirtmişlerdir. Bütün katılımcılar İnternet'i bir araştırma ortamı olarak kullandıklarını söylemişlerdir. İnternet'in araştırma ortamı olarak kullanılmasından sonra gelen en yoğun yararlanılma amacı iletişim hizmetleridir $(n=202, \% 98)$. Araştırmacıların İnternet'i öğretim ortamı olarak kullanım düzeyleri $(n=$ $160, \% 77)$ ile video izleme - müzik dinleme $(\mathrm{n}=159, \% 77)$ ve banka işlemleri $(\mathrm{n}=164, \% 79)$ kullanım oranları eşit seviyededir.

\section{İstatistiksel Çözümlemeler}

Frekans - yüzde belirlemek ve ki-kare analizlerini yapmak için SPSS (Sosyal Bilimler için İstatistik Paketi) ile Microsoft Ofis Excel programı birlikte kullanılmıştır. Betimsel istatistikler ile tek örneklem için kullanılan ki-kare testinden nicel verilerin özetlenmesi ve sunulması adına yararlanılmıştır. Katılımcıların cinsiyet, yaş, deneyim ve bölümleriyle sosyal medya kullanım düzeyleri arasındaki ilişkileri araştırmak için ki-kare testi uygulanmıştır. Ek olarak, açık uçlu anket sorularından elde edilen nitel veriler, eğitim araştırmacılarının görüşlerinden daha derinlemesine bilgi sağlamak için içerik analizi yöntemiyle çözümlenmiştir. Sosyal medyanın eğitim çalışmalarındaki tasarımına yönelik sınırlı sayıda araştırma olduğu göz önüne alındığında, eğitim araştırmacılarının görüşlerinin irdelenmesi boyutunda keşfedici araştırmalarda da özellikle önerilen nitel yöntem kullanılmıştır. Açık uçlu sorulardan elde edilen cevaplar, araştırmacı ve araştırma sorularından haberdar olmayan 
bir alan uzmanıyla birlikte değerlendirilmiştir. Tüm nitel veriler birden çok kez gözden geçirilmiştir. Elde edilen kodlar oluşturulan temalar içine yerleştirilmiştir. Çözümlemeler bu kodlara dayalı olarak yapılmıştır. Araştırmanın geçerliği konusunda elde edilen bulguların birbiriyle tutarlı olduğu ve genel olarak durumu yansıttığ gözlemlenmiştir. İçerik analizi güvenilirliği için hesaplanan Krippendorff’un Alpha katsayısı .879 bulunmuştur.

\section{Bulgular}

\section{Eğitim Araştırmacılarının Sosyal Medya ve Web 2.0 Teknolojilerine İlişkin Bilgi ve Kullanım Düzeyleri}

Sosyal medyayı geliştiren yapı Web 2.0 teknolojisidir. Çözümleme sonuçlarına göre (Tablo 1), eğitim araştırmacılarının 142'si (\%69) sosyal medya hakkında bilgi sahibi olsa da sadece 60 araştırmacı (\%29) Web 2.0 teknolojilerini bildiklerini belirtmiştir. 2 araştırmacı (\%1) sosyal medya hakkında bir şey bilmediğini söylerken, 88 eğitim araştırmacısı da (\%43) Web 2.0 teknolojileri hakkında bilgilerinin olmadığını ifade etmiştir. Ayrıca, 167 katılımcı (\%81) mikro ve makro blog arasındaki farktan habersiz olduklarını dile getirmiştir. Bu noktada eğitim araştırmacılarının sosyal teknolojilerin nasıl adlandırıldığının bilmedikleri ortaya konulmuştur. Aslında, Twitter ve BlogSpot'un ne olduğunu bilmelerine karşın bunların mikro ya da makro blog olarak isimlendirilmelerine neden olan farklılıklardan haberdar değillerdir. Ancak, eğitim araştırmacılarının Web 2.0 ve sosyal medya ile ilgili bilgi düzeylerinin oldukça yüksek olduğu söylenebilir. Biraz teknik desteğe gereksinim duyulduğu ifade edilebilir.

Tablo 1. Eğitim Araştırmacılarının Sosyal Medya ve Web 2.0 Teknolojilerine İlişkin Bilgi Düzeyleri

\begin{tabular}{lcclcc}
\hline \multicolumn{2}{c}{ Sosyal Medya Bilgi Düzeyi } & & \multicolumn{3}{c}{ Web 2.0 Bilgi Düzeyi } \\
\hline Yeterli bilgim var & $\mathrm{f}$ & $\%$ & & $\mathrm{f}$ & 60 \\
Kismen biliyorum & 142 & 69 & Yeterli bilgim var & 59 & 29 \\
Bilgim yok & 63 & 30 & Kismen biliyorum & 88 & 28 \\
\hline
\end{tabular}

Eğitim araştırmacılarının çoğu $(n=177, \% 86)$ bir sosyal ağ üyeliğine sahiptir. Sosyal medyaya katılım durumları incelendiğinde (Tablo 2), sadece 42 araştırmacının (\%20) sosyal medyada paylaşımlar hakkında genel olarak yorum yazdığı görülmüştür. 64 katılımcı (\%31) hiç yorum yazmazken, 101 araştırmacı (\%49) bazen yazdığını ifade etmiştir. Ayrıca, araştırmacıların büyük çoğunluğu $(n=126, \% 61)$ kendisine ait bir blog sayfasına sahip değildir ve başkalarına ait bir web günlüğünü takip etmemektedir $(\mathrm{n}=108, \% 52)$. Bunlarla beraber katılımcılar forumları takip etme eğilimindedirler $(n=130, \% 63)$ ve anlık mesajlaşma programlarını kullanmaktadırlar $(\mathrm{n}=172, \% 83)$. Bu noktada eğitim araştırmacılarının sosyal medyada paylaşımda bulunmayı tercih etmedikleri bunun yerine günlük yaşam gereksinimleri adına İnternet üzerinde forum ve anlık mesajlaşma sistemlerini kullandıkları söylenebilir. Sosyal ağ üyelikleri bu ortamların popülerliğinden kaynaklanmakta, kendileri için kullanım düzeyleri oldukça düşük kalmaktadır. Eğitim araştırmacılarının sosyal medyayı etkin biçimde kullanmadıkları görülmüştür. Eğitim çalışmalarında sosyal medya özelliklerinden yararlanmak adına eğitim araştırmacılarının sosyal medya araçlarından haberdar olmalarının olumlu yansımaları görülebilir. Bu konuda eğitim araştırmacılarının bilişim teknolojileri eğitimcileri, eğitim teknolojisi uzmanları veya öğretim tasarımcıları tarafından sunulacak destek ve rehberliğe gereksinimleri olabilir.

Tablo 2. Eğitim Araştırmacılarının Sosyal Medya Kullanım Oranları

\begin{tabular}{lcccc}
\hline & \multicolumn{2}{c}{ Var } & Yok & n \\
\hline Sosyal ă̆ hesabı & $\mathrm{n}$ & $\%$ & 30 & 14 \\
Kendine ait blog hesabı & 177 & 86 & 126 & 61 \\
Takip ettiği blog sayfası & 81 & 39 & 108 & 52 \\
Takip edilen forumlar & 99 & 48 & 77 & 37 \\
Kullanılan anlık mesajlaşma programı & 130 & 63 & 35 & 17 \\
Video paylaşım sitelerinde yapılmış paylaşım & 172 & 83 & 182 & 88 \\
Fotoğraf paylaşım sitelerinde yapılmış paylaşım & 25 & 12 & 188 & 91 \\
\hline
\end{tabular}

Tablo 3 incelendiğinde katılımcıların çoğunun $(n=129, \% 62)$, önceki eğitim çalışmalarında sosyal medyayı kullandığı görülmektedir. Daha önce yaptıkları araştırmalarda sosyal medyayı kullanmamış olan 78 araştırmacıdan 18'i (\%23) gelecekteki eğitim çalışmalarında da sosyal medyayı kullanmayı düşünmediklerini ifade etmişlerdir. 
Daha önce yaptıkları araştırmalarda sosyal medyayı kullanan araştırmacılardan ise sadece üçü (\%2) gelecekteki çalışmalarında tekrar kullanmayı düşünmediğini söylemiştir. Toplamda tüm katılımcıların sadece \%10'u gelecekteki eğitim çalışmalarında sosyal medyadan yararlanmayı düşünmemektedir. Bu noktada daha önceki araştırmalarında sosyal medyayı kullanan araştırmacıların daha sonraki çalışmalarında da kullanmayı planladıkları, geçmişteki araştırmalarında sosyal medyadan yararlanmayan eğitim araştırmacılarının da çoğunluğunun gelecekteki çalışmalarında sosyal medyayı kullanmayı düşündükleri görülmüştür. Bu bulguya dayanarak, eğitim çalışmalarında sosyal medyanın daha yoğun olarak kullanılacağı söylenebilir. Doğru kullanım açısından alan uzmanlarına büyük sorumluluk düşmektedir. Sosyal medya ögeleri açısından katılımcıların daha çok sosyal ağ hizmetlerini $(\mathrm{n}=86, \% 42)$ kullandıkları ve eğitim çalışmalarında sosyal ağlardan $(\mathrm{n}=156, \% 75)$ yararlanmayı planladıkları görülmüştür. Diğer popüler sosyal medya ve Web 2.0 araçları anlık mesajlaşma sistemleri, forumlar ve web günlükleridir. Bu noktada, eğitim araştırmacılarının iyi bildikleri ve günlük yaşamlarında kullandıkları sosyal medya ögelerinden daha fazla yararlandıkları söylenebilir.

Tablo 3. Eğitim Araştırmacılarının Çalışmalarında Sosyal Medyadan Yararlanma Durumları Önceki Eğitim Çalışmalarında Sosyal Medyadan Gelecekteki Eğitim Çalışmalarında Sosyal Yararlanılma Durumu Medyadan Yararlanılma Durumu

\begin{tabular}{|c|c|c|c|c|c|}
\hline & $\mathrm{n}$ & $\%$ & & $\mathrm{n}$ & $\%$ \\
\hline Kullanmadım. & 78 & 38 & Kullanmayı düşünmüyorum. & 21 & 10 \\
\hline Sosyal ağları kullandım. & 86 & 42 & Sosyal ağları kullanabilirim. & $\begin{array}{c}15 \\
6\end{array}$ & 75 \\
\hline Blogları kullandım. & 58 & 28 & Blogları kullanabilirim. & $\begin{array}{c}10 \\
3\end{array}$ & 50 \\
\hline Video paylaşım sitelerini kullandım. & 45 & 22 & Video paylaşım sitelerini kullanabilirim. & 88 & 43 \\
\hline Fotoğraf paylaşım sitelerini kullandım. & 24 & 12 & $\begin{array}{l}\text { Fotoğraf paylaşım sitelerini } \\
\text { kullanabilirim. }\end{array}$ & 57 & 28 \\
\hline Forumları kullandım. & 63 & 30 & Forumları kullanabilirim. & $\begin{array}{c}11 \\
5\end{array}$ & 56 \\
\hline Anlık mesajlaşma sistemlerini kullandım. & 71 & 34 & $\begin{array}{l}\text { Anlık mesajlaşma sistemlerini } \\
\text { kullanabilirim. }\end{array}$ & $\begin{array}{c}11 \\
2\end{array}$ & 54 \\
\hline Diğer sosyal medya ögelerini kullandım. & 43 & 21 & $\begin{array}{l}\text { Diğer sosyal medya ögelerini } \\
\text { kullanabilirim. }\end{array}$ & 74 & 36 \\
\hline
\end{tabular}

\section{Araştırmacı Özellikleri ile Sosyal Medya Kullanımları Arasındaki İlişki}

Katılımcıların; cinsiyet, yaş (20-29, 30-39, 40 ve üzeri) ve araştırma deneyimleri (1-5, 6-10, 11-15, 15 ve üzeri) ile sosyal medya, Web 2.0 teknolojileri ve web günlüklerine ilişkin bilgi düzeyleri arasında herhangi anlamlı bir ilişki görülmemiştir. Bu durum, aynı bölümlerdeki tüm eğitim araştırmacılarının sosyal medya, Web 2.0 ve bloglar hakkında benzer bilgi düzeyine sahip olduğunu göstermektedir.

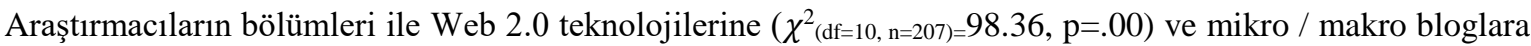
$\left(\chi_{(\mathrm{df}=5, \mathrm{n}=207)}^{2}=61.74, \mathrm{p}=.00\right)$ iliş̧kin bilgi düzeyleri arasında anlamlı bir ilişki bulunmuştur. Bu ilişki incelendiğinde Bilgisayar ve Öğretim Teknolojileri Eğitimi (BÖTE) bölümünde çalışan araştırmacıların Web 2.0 teknolojileri ve web günlükleri konusunda diğer bölümlerdeki araştırmacılardan daha fazla bilgiye sahip oldukları görülmüştür. Benzer bir durum diğerlerine ait blogların $\left(\chi_{(\mathrm{df}=5, \mathrm{n}=207)}^{2}=11.54, \mathrm{p}=.04\right)$ ve genel forumların $\left(\chi_{(\mathrm{df}=5, \mathrm{n}=207)}^{2}=11.70\right.$, $\mathrm{p}=.04)$ takibi konusunda da geçerlidir. Bunun ana nedeni olarak BÖTE'nin Türkiye'deki eğitim fakültelerinde diğer bölümlere oranla daha teknik bir bölüm olması gösterilebilir.

15 yıl ve üzeri deneyime sahip 40 yaş ve üstü araştırmacıların, eğitim çalışmalarında sosyal medyadan daha az yararlandıkları ve gelecekte daha az yararlanmayı düşündükleri görülmüştür. $\mathrm{Bu}$ durum istatistiksel olarak da

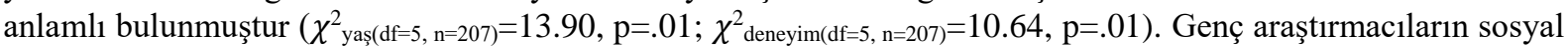
medyadan daha fazla yararlanmaları sosyal medyaya sağladıkları uyum ve daha yoğun kullanımlarıyla ilişkilendirilebilir.

Bilgi ve iletişim teknolojilerini kullanma yeteneğinin eğitim araştırmalarında sosyal medyayı kullanma üzerinde herhangi bir etki yaratmadığı görülmüştür. Bu durumun sosyal medyanın kullanım kolaylı̆̆ından ve üst düzey bilişim teknolojisi becerisi gerektirmemesinden kaynaklandığg söylenebilir. 
Ancak, sosyal medyayı üst düzeyde kullanmanın (blogların özelliklerinin bilinmesi $\left[\chi^{2}(\mathrm{df}=1, \mathrm{n}=207)=4.87, \mathrm{p}=.03\right]$, diğerlerine ait blogların $\left[\chi_{(\mathrm{df}=1, \mathrm{n}=207)}^{2}=10.54, \mathrm{p}=.001\right]$ ve forumların $\left[\chi_{(\mathrm{df}=1, \mathrm{n}=207)}^{2}=10.63, \mathrm{p}=.001\right]$ takip edilmesi) eğitim çalışmalarında sosyal medya ögelerinden daha yoğun yararlanma arasında anlamlı bir ilişki olduğu görülmüştür. Sosyal medyayı detaylı olarak kullanan eğitim araştırmacılarının, bu ayrıntılı özellikleri eğitim çalışmalarında da kullanmak istedikleri ifade edilebilir.

BÖTE bölümünde görevli araştırmacıların sosyal medyadan daha fazla yararlandıkları bulunmuştur $\left(\chi^{2}\right.$ (df $=5$,

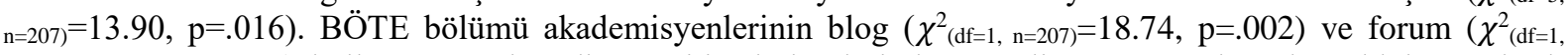
$\mathrm{n}=207)=13.83, \mathrm{p}=.017)$ kullanım oranları diğer eğitim bölümlerinde görevli araştırmacılarından oldukça yüksek çıkmıştır. Bu bulgu, daha önceden de bahsedilen sosyal medya ve Web 2.0 teknolojilerinin özelliklerini bilen ve detaylı biçimde kullanan araştırmacıların akademik çalışmalarında da bu özelliklerden yararlanmayı istedikleri bulgusuyla da uyumludur. Eğitim araştırmacılarının eğitim çalışmalarında sosyal medyadan yararlanma durumlarının yalnızca sosyal medyayı kullanmalarıyla değil, aynı zamanda sosyal medyanın gücünü tanımalarıyla da ilişkili olduğu söylenebilir.

\section{Sosyal Medyanın Eğitsel Çalışmalar İçerisinde Kullanımına İlişkin Görüşler}

Çözümleme sonucu elde edilen bulgular, araştırmacıların sosyal medyayı eğitim çalışmalarında kullanma konusunda olumlu düşündüklerini göstermektedir (Tablo 4).

EA10: "Şu anda seçmeli bir derste yönergeleri verme, ürünleri paylaşma, araştırma yapma gibi konularda kullanıyorum. Yaş gruplarına göre çeşitli sınırlandırmalar getirilerek kullanılması taraftarıyım."

EA61: "Çalışma alanlarım arasında olduğundan dolayı yakından takip ediyorum. Bilgisayar dersine girdiğimde öğretmen adaylarına kullanımı konusunda uygulamalı eğitim veriyorum. Çă̆ımız teknoloji ve bilişimin hayatımızda vazgeçilmez olmaya başladı̆̆ bir çă̆, bu nedenle ögretmenlerin ve öğrencilerin kullanmasını faydalı buluyorum. Küçük çocuklar bile facebook hesapları ile internette saatler geçiriyorlar, bence bu sosyal ă̆ları eğitim amaçlı kullanmak onların daha çok ilgisini çekebilir."

Tablo 4. Sosyal Medyanın Eğitim Çalışmalarında Kullanılmasına İlişkin Görüşler

\begin{tabular}{lcc}
\hline Sosyal Medya Kullanımı ile İlgili Görüşler & $\mathrm{f}$ & $\%$ \\
\hline Çok önemli, kullanılmalı & 19 & 9 \\
Kullanıyorum, gelecekte kullanmaya devam edeceğim & 8 & 4 \\
Kullanılabilir & 154 & 74 \\
Kullanmıyorum, gelecekte kullanabilirim & 8 & 4 \\
Kullanmıorum, gelecekte kullanmayı düşünmüyorum & 10 & 5 \\
İşe yaramaz görüyorum & 8 & 4 \\
\hline
\end{tabular}

Sadece 18 katılımcı sosyal medyayı eğitim çalışmalarında kullanmadığını ve kullanmayı düşünmediğini belirtmiştir. Yararlanma planı olmayan eğitim araştırmacıları sosyal medya gibi bir ortama ihtiyaç duymadıklarını ya da bu ortamdaki çalışmalar için hazırlıklı olmadıklarını ifade etmişlerdir.

EA82: “Bölümüm nedeniyle sosyal ă̆lara yönelik herhangi bir çalışma yapmadım."

EA115: "Şimdilik paylaşım için yeterli materyal hazırlayamadığım için kullanmıyorum."

EA194: "Sosyal medyanın kullanıldı̆̆ çalışmaları inceleme firsatım olmadı. Açıkçası daha önce hiç de denk gelmedim. Sosyal medyayla çok fazla haşır neşir olmadığım için eğitim alanında nasıl kullanılabilirim bilmiyorum."

Sosyal medyanın eğitim çalışmalarına sağlayacağı katkılar ve sınırlılıklarına ilişkin katılımcı görüşleri de Tablo 5'de sunulmuştur.

Tablo 5. Sosyal Medyanın Eğitim Çalışmalarındaki Katkıları ve Sınırlılıklarına İlişkin Görüşler

\begin{tabular}{lcclcc}
\hline \multicolumn{1}{c}{ Katkıları } & $\mathrm{f}$ & $\%$ & \multicolumn{1}{c}{ Sınırlılıkları } & $\mathrm{f}$ & $\%$ \\
\hline Geniş kitlelere ve verilere erişim & 45 & 29 & Güvenirlik & 32 & 64 \\
Güncellik & 36 & 23 & Alan yazın eksikliği & 7 & 14 \\
Etkililik & 31 & 20 & Belli bir kitle ve içeriğe uygunluğu & 3 & 6
\end{tabular}


Katılımcılara göre geniş kitlelere ve verilere erişim $(f=45, \% 29)$ sosyal medyanın eğitim araştırmalarına sağladığı en önemli katkıdır.

EA2: "Bence kullanılmall, eğitim araştırmalarında zaman konusunda tasarruf să̆lar. Bir eğitimci için zaman en dikkat edilmesi gereken unsurlardan birisidir. Ekonomik yönden ise birçok kişiye masrafsız rahatlıkla ulaşabilirsiniz."

EA22: "Daha fazla veriye ulaşma açısından kesinlikle kullanılması gerektiğini düşünüyorum.”

EA44: "Sosyal ağların geçmiş 1-2 yıldaki kullanıcı sayısındaki büyük artış ve gençlerin bu sitelere olan bă̆ımlılı̆̆ d düşünüldügünde sosyal medyanın eğitim araştırmalarında kullanılabileceğini düşünüyorum."

EA85: "Sosyal medyanın popüler ve kullanım kolaylı̆̆ının olması ve birçok kitleye kolayca ulaşma özelliği eğitim için kullanılabileceğini gösterir."

Araştırmacılar sosyal medyanın diğer olumlu yönleri olarak güncelliğini ( $f=36, \% 23)$, etkili olmasını ( $f=31$, \%20), katılımcılığını ( $\mathrm{f}=26, \% 17)$ ve uygulama kolaylığını $(\mathrm{f}=16, \% 10)$ göstermişlerdir.

EA13: “Gün geçtikçe sosyal medyanın hayatımızda kapladı̆̆ yer artmaktadır. Öyle ki artık sadece bilgisayar başında olduğumuz zaman değil hemen hemen her an sosyal medyayı takip eder hale geldik. Günlük hayatımıza bu kadar derinden tesir eden uygulamaların eğitim araştırmaları alanında da kullanılmaması bence düşünülemez."

EA15: “Formal bir yapıdan kurtulmuş kişiler, çoğunlukla sosyal medyada düşüncelerini birbiriyle daha rahat paylaşırlar. Ayrıca sosyal medyanın gücü ve etki alanı düşünüldügüunde mutlaka bu ortamların da eğitim araştırmalarında kullanılması gerektiğini düşünüyorum.”

EA18: "Yararlı olabileceğini düşünüyorum. Çünkü derslerimde etkili olmasından dolayı kullanmaya devam ediyorum."

EA20: "Derslerimde blog ortamından yararlanıyorum. Ders dokümanlarını paylaşılması, ders ile ilgili tartışmaların gerçekleştirilmesi açısından oldukça faydalı."

EA24: "Sosyal medyanın güncelliğine ve paylaşım konusundaki genişliğine inandığım için kullanılması gerektiğini düşünüyorum. Sonuçta eğitim araştırmalarında hatta her türlü araştırmada güncellik önemli. "

EA27: “Özellikle internet destekli eğitim için sosyal bir ortam yaratması, kolay kullanılır olması ve özgürce kendini ifade edebilme özellikleri ile öne çıktı̆̆ını düşünüyorum; ayrıca günümüz kuşağının büyük bir bölümünün kullanıyor olması da önemli bir neden olarak gösterilebilir."

EA55: "Bence sosyal medya ortamları öğrencilerin çoğu tarafindan da kullanıldı̆̆ için araştırmalarda faydalanılabilecek ortamlar. Ben blog, video paylaşım ve sosyal medya ortamlarını araştırmalarımda kullanıyorum ve çok memnunum. Çünkü öğrenci ortamları bildiği için bu teknolojilerin kullanımından çok yapacakları etkinliklere odaklanabiliyorlar."

EA121: “Öğrencilerimiz tahmin edemeyeceğimiz boyutta değiştiler ve tamamen bir dijital yaşamda yaşıyorlar. Biz ĕgitimciler, 21. yüzyıl becerilerini onlara kazandırabilmek için onları iyi tanımalı ve ögrenme ortamlarını çă̆a uygun hale getirmemiz gerekiyor. Sosyal medya bu anlamda eğitimcilere oldukça elverişli ortamlar sunuyor."

EA130: "Son dönem ĕgitim araştırmalarının birçoğunda sosyal medyadan faydalanıldı̆̆ını görüyoruz. Artık üniversite öğrencilerinin de dijital yerli olduğu göz önüne alınırsa, bunun seçimden ziyade bir gereklilik olduğunu düşünüyorum. Eğitimin temelinde insan, insanların etkileşiminde iletişim temel unsur olduğuna göre, çağın gerektirdiği iletişim araçlarını kullanmak son derece sıradan bir durum artık."

Sosyal medyanın eğitim çalışmalarında kullanılmasına dair en yoğun olumsuz görüş olarak güvensiz bir ortam olması ( $(\mathrm{f}=32, \% 64)$ dile getirilmiştir.

EA6: "Yeteri kadar güvenilir bulmuyorum." 
EA42: "Güvenirliliği sağlamak daha zor diye düşünüyorum."

EA57: “Kullanım sürecinde güvenilirliği să̆lamanın güç olduğunu, kullanılacak alanlar konusunda detaylı bilgi edinilmesi gerektiğini ve kullanıcının yeterliğinin üst düzeyde olması gerektiğini düşünüyorum.”

EA108: "Bana sosyal medya sanal medya gibi geliyor."

EA201: "Güvenilirliği konusunda endişeler olduğunu düşünüyorum."

Ayrıca alan yazın eksikliği ( $f=7, \% 14)$ ve belli bir kitle ve içeriğe uygunluğu $(f=3, \% 6)$ diğer sınırlılıklar olarak düşünülmektedir.

EA23: "Sosyal medyanın eğitim çalışmalarında etkili kullanılmasını sağlayacak yeterli kuramsal ve uygulamalı çalışmaların gerçekleştirildiğini düşünmüyorum."

EA32: "Sosyal medya, eğitimi bir yönüyle kolaylaştırıp destekliyor. Konuya göre sosyal medyanın her uygulama için uygun olduğunu düşünmüyorum. Uygun olanlarının da kullanılması için bulunmaz bir ortam olduğunu düşünüyorum. Sosyal medya ve araştırma yöntemi konusunda da henüz bir fikir birliğine varıldı̆̆ını düşünmüyorum. Çalışmanın türüne, örnekleminde ve konusuna göre bu farkl araştırmacının tespit etmesi (doğruya yakın bir tespit yapması) gerekir. Şahsen ben hem nitel hem de nicel bilginin doğru alınacağını/alındı ̆̆ını düşünmüyorum. Sosyal medyadan bilgi alma ve analiz etme ile ilgili yeni bir söylemin (türün) geliştirilmesinin doğru olduğunu düşünüyorum."

EA38: "Sadece interneti ve sosyal medyayı kullanan kişilere hitap ediyor."

EA116: "Bugün sosyal medya ve eğitim ilişkisi bizim için pek çok yönüyle ele alınması gereken kocaman bir sorun. Alan yazındaki kuramsal temelleri açık biçimde ortaya konulamamıştır."

Araştırmacıların sosyal medyanın kullanılacağı bir eğitim araştırmasının veri toplama yöntemi ve araştırma tasarımına ilişkin görüşleri Tablo 6'da sunulmuştur.

Tablo 6. Sosyal Medya Kullanılacak Eğitim Araştırmaları İçin Veri Toplama Yöntemi ve Araştırma Tasarımına İlişkin Görüşler

\begin{tabular}{|c|c|c|c|c|c|}
\hline \multicolumn{3}{|c|}{ Tercih edilen veri toplama yöntemi } & \multicolumn{3}{|c|}{ Veri toplama yöntemini tercih etmede dikkat edilen noktalar } \\
\hline & $\mathrm{f}$ & $\%$ & & $\mathrm{f}$ & $\%$ \\
\hline Karma & 82 & 42 & Nitel ve nicelin tamamlayıcılığ1 & 49 & 27 \\
\hline Sadece nitel & 37 & 19 & Güvenilirlik & 38 & 21 \\
\hline Sadece nicel & 37 & 19 & Araştırma sorusuna göre belirlenir & 38 & 21 \\
\hline Hepsi ayrı ayrı & 41 & 20 & Sosyal medyanın sadece nitel tasarıma & 18 & 10 \\
\hline \multirow[t]{5}{*}{ kullanılabilir } & & & uygunluğu & & \\
\hline & & & Daha fazla veriye ulaşma çabası & 14 & 8 \\
\hline & & & Hizlı uygulama & 11 & 6 \\
\hline & & & $\begin{array}{l}\text { Sosyal medyanın sadece nicel tasarıma } \\
\text { uygunluğu }\end{array}$ & 7 & 4 \\
\hline & & & $\begin{array}{l}\text { Tüm araştırma tasarımı için sosyal } \\
\text { medyanın uygunluğu }\end{array}$ & 6 & 3 \\
\hline \multicolumn{3}{|c|}{ Tercih edilen araştırma tasarımı } & \multicolumn{3}{|c|}{ Araştırma tasarımında dikkat edilen noktalar } \\
\hline & $\mathrm{f}$ & $\%$ & & $\mathrm{f}$ & $\%$ \\
\hline Deneysel model & 96 & 59 & Güvenilirlik & 58 & 45 \\
\hline Tarama modeli & 31 & 19 & Araştırma sorusu & 36 & 28 \\
\hline \multirow[t]{2}{*}{ Karma model } & 35 & 22 & Özgünlük & 13 & 10 \\
\hline & & & Uygulama kolaylığ1 & 13 & 10 \\
\hline
\end{tabular}

Tablo 6 incelendiğinde, eğitim araştırmacılarının sosyal medyanın kullanılacağı araştırmalar için deneysel model ( $\mathrm{f}=96, \% 59)$ içerisinde karma yöntemi $(\mathrm{f}=82, \% 42)$ tercih ettikleri görülmüştür.

EA1: "Sosyal medyada gerçekleşecek çalışmada etkili olmak istiyorsak ĕger, kurgulanmış araştırma düzeni gibi deneysel tasartmlar tercihimdir." 
EA11: "Deneysel model tercih ederim. Nedeni de önceden düzenlenmiş bir sistem aracıliğ ile toplanan verinin analizi, rastgele hazırlanan bir ortamdan elde edilen verinin analizinden daha kolaydır."

EA13: "Sosyal medyanın gerek nitel gerekse nicel araştırmalar için uygun olduğunu düşünmekteyim. Bundan dolayı karma veri toplama yöntemi oldukça uygun görülmektedir. Kullanılacak model araştırmanın çeşidine göre değişebilir ancak yapılandırılmış bir araştırmanın, araştırmanın hedefine ulaşmasını kolaylaştıracak sonuçlar sağlayabileceğini düşünmekteyim. Bundan dolayı da deneysel desene öncelik veririm."

EA20: "Karma yöntemi tercih ederim. İki araştırma yönteminden elde edilen sonuçları karşılaştırma, araştırma alt problemlerini derinlemesine inceleme amaçll."

EA23: "Karma. Çünkü sadece nicel ya da nitel veri ile güvenilir sonuçlara ulaşılamayacağına inanıyorum. Deneysel düzeni seçmenin de istenen sonuçlara ulaşmada daha etkili olabileceğini düşünüyorum."

EA26: "Deneysel araştırma düzenini tercih ederim. Çünkü öğrenenlerin öğretim sürecinde yönlendirilmeleri çok önemlidir. Diğer türlü amacımıza ulaşmamız zorlaşabilir.”

EA44: “Deneysel kullanmayı tercih ederim çünkü eğitimsel araştırmalarda özgünlük önemli bir unsurdur."

Eğitim araştırmacılarına göre veri toplama yöntemini tercih etmede dikkati çeken önemli noktalar, nicel ve nitelin bütünlüğü sağlaması $(\mathrm{f}=49, \% 27)$, güvenirlik $(\mathrm{f}=38, \% 21)$ ve araştırma sorusudur $(\mathrm{f}=38, \% 21)$.

EA5: "Nicel ă̆ırlıklı olur nitelde biraz daha açıklayıcı bilgi elde etmek istiyorsak duruma göre soru sorabilmeliyiz."

EA16: “Bir anket çalışması yapılarak yüzeysel ve genel bilgiler elde edilirken, görüşmeler ile daha derin ve özel bilgiler elde edilebilir. Böylece bütünlük sağlanmış olur."

EA39: "Nitel, Nicel ve Karma yöntemler birbirinden farklı özellikleri olan ve farklı durumları ilgilendiren yöntemler olduğu için araştırma soruma en iyi cevabı bulabileceğim yöntemi tercih ederim."

EA46: "Karma veri toplama yöntemini tercih ederim. Zira sadece nitel veya nicel çalışmaların durumların ortaya konması konusunda çok yeterli olmadığ kanaatindeyim. Nicel verilerle alınan sonuçların nitel görüşme ve gözlemler desteklenmesi elde edilen verilerin güvenirliğini arttıracağını düşünüyorum."

EA57: “Nitel başta olmak üzere Nitel ya da Karma yöntemi tercih ederim. Tercih nedenlerim ise derinlemesine veri elde etmek, farklı veri kaynaklarını ve veri toplama araçlarını kullanarak güvenilirliği arttırmak, kişilerin yaşantıları ve algılarına ilişkin daha kapsamlı bilgi etmek olarak siralanabilir."

EA63: "Karma yöntem olur sanırım. Nitel veriler ve nicel verilerin birlikteliği gerekecektir."

EA88: “Karma. Çünkü nicel olarak yapılan çalışmanın nitel olarak da yapıldı̆̆ında elde edilen bulguların birbirini destekleyip desteklemediğini görmek açısından tercih ederim."

EA184: “Araştırmanın konusuna, verilerine göre değişir kullanacă̆ım yöntem."

Sosyal medyadan yararlanılacak eğitim araştırmalarının tasarımında da güvenilirlik $(f=58, \% 45)$, araştırma sorusu ( $f=36, \% 28)$, özgünlük $(f=13, \% 10)$ ve uygulama kolaylığının $(f=13, \% 10)$ önemli olduğu katılımcılar tarafından belirtilmiştir.

EA38: "Tasarımlar araştırmanın amacına ve metoduna göre değişecektir."

EA41: "Araştırma soruma bağlı olur bu durum. Hangisi duruma daha uygunsa onu tercih ederim."

EA145: “Ĕ̆itim bilimciler normal şartlarda hangi yaklaşımları kullanıyorlarsa sosyal medya aracılı̆̆ıyla yapılan çalışmalarda da aynı yaklaşımlar kullanılmalıdır çünkü araştırmanın güvenirliği sağlamak önemlidir."

EA187: "Kesinlikle kullanılmalı ancak doğru bilgiler olmalı kesinlikle."

\section{Tartışma, Sonuç ve Öneriler}

Katılımcıların tamamının İnternet'i bir araştırma ortamı olarak kullandıkları bulunmuştur. İnternet'in sağladığ olanaklardan dolayı bu oldukça doğal karşılanmaktadır. Frankel ve Siang (1999), İnternet'in büyüyen bilgi havuzuna katkıda bulunduğunu, araştırmacılara coğrafi ve kültürel açıdan farklı bir popülasyona potansiyel erişim sağladığını belirtmektedirler. Bu nedenle, eğitim araştırmacıları da çalışmalarında İnternet'ten yararlanmayı 
istemektedirler. Ancak sosyal medyanın eğitsel ortam olarak profesyonel kullanımında yönelik yeterli ampirik çalışma bulunmamaktadır (Popa ve Voinea, 2017). Grosseck ve Holotescu (2011)'ya göre, akademik araştırmalarda mikro blog kullanımı araştırmacılar için popüler bir sosyal medya konusudur. Benzer şekilde Sullivan (2017), araştırmacıların araştırma ve öğretim materyalleri bulmak için Google Akademik, RSS ve Pinterest'ten yararlandıklarını ifade etmektedir. Çalışmada eğitim araştırmacılarının İnternet'i iletişim, öğretim ve eğlence gibi günlük ve profesyonel amaçlı kullandıkları görülmüştür. Bu aktiviteler için İnternet üzerinden sunulan Web 2.0 araçları ve sosyal medya oldukça önemlidir. Chen ve Bryer (2012) sosyal medyanın kişisel ya da akademik ve araştırma gibi mesleki amaçlar için de kullanıldığını belirtmişlerdir. Benzer şekilde, Cao, Ajjan ve Hong (2013) ile Veletsianos (2013), akademisyenlerin kişisel ve mesleki amaçlar için sosyal medya uygulamalarını kullandıklarını ifade etmektedirler. Gülbahar ve arkadaşlarının (2017) çalışmasında ise Almanya, Rusya, İsviçre ve Türkiye'de çalışan öğretim elemanlarının sosyal medyayı özel amaçlar için daha aktif olarak kullandıkları tespit edilmiştir. Manca ve Ranieri (2016)'nin çalışmasının genel yargısı, kişisel kullanımın neredeyse her zaman mesleki kullanımla ilişkili olduğu yönündedir. Benzer olarak bu çalışmada da sosyal medyadan günlük hayatında daha ayrıntılı faydalanan araştırmacıların eğitim çalışmalarında da bu detay özelliklerden yararlandıkları görülmüştür.

Web 2.0 ve sosyal medya İnternet'in önemli bir parçası olsa da her İnternet kullanıcısı bunları kullanmayabilmektedir. Bu çalışmada da tüm katılımcılar İnternet'i kullanmaktayken, \%69'u sosyal medyayı ve \%30'u Web 2.0 teknolojilerini bilmektedir. Sosyal medya ve Web 2.0'ın günlük yaşamda oldukça popüler olmasına karşın iki araştırmacının (\%1) sosyal medya hakkında hiçbir şey bilmediği ve 88 araştırmacının (\%43) da Web 2.0 teknolojileri hakkında bilgiye sahip olmadıkları görülmüştür. 2009 yılında Amerika Birleşik Devletleri'ndeki 50 yüksekokul ve üniversiteden 4 bin 600 öğretim üyesinin katıldı̆̆ 1 bir ankete göre katılımcıların \%80'inin bloglar, vikiler, Google dokümanlar, video konferanslar, video oyunlar ve sanal dünyalar gibi sosyal medya teknolojilerini bilmedikleri ya da hiç kullanmadıkları ortaya konulmuştur (Chen ve Bryer, 2012). 2010 yılında, bu konuyla ilgili bir başka araştırma, öğretmenlerin, müdürlerin ve kütüphanecilerin \%61'inin en az bir sosyal medya alanında faaliyet gösterdiğine işaret etmektedir. Bu kullanım çoğunluğunu web seminerlerine katılım, YouTube videolarını izleme, Pod yayınlarını dinleme ya da bloglara katılım gibi mesleki gelişim için olduğu belirtilmektedir (edWeb.net 2010: akt. Ferrit, 2010-2011).

Chu ve diğerleri (2017) sosyal ağ uygulama ve sitelerinin etkili bir şekilde kullanması için çok az teknolojik bilgiye ihtiyaç duyulduğunu belirtmektedirler. Bu çalışmada da katılımcıların bilişim teknolojileri becerileri düzeylerinin sosyal medya kullanımları arasında fark oluşturmadığı görülmüştür. Kullanımın kolay olması ve üst düzey bilişim teknolojileri becerisi gerektirmemesinden dolayı akademisyenlerin sosyal medya ögelerine üye olma yüzdeleri de yüksektir (Chu ve diğerleri, 2017). Ancak eğitim araştırmacıları sosyal medyayı yeterince etkin kullanmamaktadırlar. Örneğin bu çalışmada, katılımcıların önemli bir çoğunluğu (n = 177, \%86) sosyal ağ üyeliğine sahip olmasına karşın sadece 42 araştırmacının $(\% 20)$ sosyal medyadaki paylaşımlarda yorum yazdığ görülmüştür. 64 araştırmacı (\%31) hiç yorum yazmadığını belirtirken, 101 araştırmacı (\%49) bazen yorum yazdığını söylemiştir. Aynı zamanda araştırmacıların çoğunun $(n=126, \% 61)$ bir blog sayfasına sahip olmadığ ve başkalarına ait bir blogu takip etmedikleri $(\mathrm{n}=108, \% 52)$ bulunmuştur. Katılımcılar forumları takip etme $(\mathrm{n}=$ 130, \%63) ve anlık mesajlaşma programlarını kullanma $(n=172, \% 83)$ eğilimi gösterirken video ya da fotoğraf paylaşmayı tercih etmemektedirler. Benzer biçimde Çelik ve diğerlerinin (2014) çalışmalarında da Türkiye'deki yükseköğretimde görevli eğitimcilerin sosyal medya hesaplarına sahip olmalarına karşın etkin bir sosyal medya kullanıcısı olmadıkları görülmüştür.

Cao ve arkadaşlarına (2013) göre eğitimciler sınıf etkinliklerinde sosyal medya uygulamalarını kullanmaktadırlar. Farklı sosyal ortamlar (ör. Facebook, Flickr, PBworks, Twiter, WordPress, YouTube), sınıf içidışı etkinlikler açısından eğitimciler ile öğrencilere özel araçlar sunmaktadır (Dabbagh ve Kitsantas, 2012). Gao, Luo ve Zhang (2012) ile Veletsianos (2013) de blogların ve diğer sosyal medya araçlarının sahip oldukları öğrenmeyi teşvik etme potansiyelinden dolayı öğretim etkinliklerinde öğretim elemanlarına yardımcı olabileceğini belirtmektedirler. Bu keşif araştırmasında da Türk eğitim araştırmacılarının \%62'sinin daha önce yaptıkları çalışmalarda sosyal medyadan yararlandıkları ve \%90'ının gelecekteki araştırma ve öğretim etkinlikleri gibi eğitim çalışmaları için sosyal medyadan yararlanmayı düşündükleri görülmüştür. Albion (2008) eğitim ortamlarında sosyal medya gibi teknolojilerin kullanılmasının önemini belirtmekte ve eğitimcilerin kalkınma sürecinden dışlanmasının söz konusu olamayacağını ifade etmektedir.

Eğitimciler sosyal medyayı öğrenme ve öğretme sürecinde kullanırken farklı yolları tercih edebilirler (Cao vd., 2013). Örneğin, Çin'de bazı akademisyenler öğretim materyalleri bulmak adına bu teknolojilerden 
yararlanmaktadır (Sullivan, 2017). Bu çalışmada, katılımcılar özellikle sosyal ağları tercih ettiklerini $(\% 41,55)$ ve gelecekteki çalışmalarda da tercih edebileceklerini belirtmişlerdir (\%75). Benzer şekilde Çelik ve diğerleri (2014) de akademisyenlerin yoğunlukla sosyal ağları kullandıklarını bulmuşlardır. Sosyal ă̆ siteleri sahip oldukları özellikler ile formal ve informal öğrenmedeki faaliyetler için oldukça uygun olduğundan (Grosseck ve Holotescu, 2011; Mazman ve Koçak-Usluel, 2010; Veletsianos ve ark., 2013) eğitimciler tarafindan yoğun biçimde kullanılmaktadır (P. Amador ve J. Amador, 2014; Grosseck ve Holotescu, 2011; Sanchez, Cortijo ve Javed, 2014; Sarapin ve Morris, 2015).

Sosyal medyanın eğitim çalışmalarında kullanılmasıyla ilgili asıl sorun öğretim tasarımı perspektifinden etkin bir şekilde nasıl bütünleştirebileceğine ilişkin bilgi ve beceri eksikliğidir (Donelan, 2016; Gülbahar ve diğerleri, 2017; Neier ve Zayer, 2015; Rochez, 2015). Yapılan çalışmalar sonucunda sosyal medyanın eğitim amaçlı kullanılabileceğinden bahsedilmektedir (Borštnar, 2012; Wang, 2012). Ancak pek çok eğitmen, sosyal medyay1 eğitim ortamlarında nasıl kullanacaklarından emin değillerdir (Gülbahar ve diğerleri, 2017). Bir Pearson raporu, Amerikan öğretim üyelerinin \%88'inin çevrimiçi olarak buldukları kurumsal ve kullanıcı tarafindan oluşturulan videoları tavsiye durumları ya da çevrimiçi derecelendirme ve yorumlarına bağlı olarak kullandıklarını göstermektedir (Moran ve ark., 2012:akt. Cao ve ark., 2013). Kullanım açısından üzerine konulmuş bir model ya da tasarım görülmemektedir. Çalışmaya katılan eğitim araştırmacıları da alan yazın yetersizliğini önemli bir sınırlılık olarak gündeme taşımışlardır. Benzer şekilde, Ajjan ve Harsthone (2008) eğitim ortamlarında sosyal medya ve Web 2.0 araçlarının kullanımı ile ilgili çok sınırlı araştırma ve analizlerin olduğunu belirtmişlerdir. İnternet ve sosyal medyanın gerçek potansiyelinin sosyal bilimler açısından tam olarak tanınmamasından dolayı yeterli araştırma yapılamamaktadır (Wilkinson ve Thelwall, 2011). Dolayısıyla, gelecekteki eğitim araştırmalarında sosyal medyayı kullanmaya odaklanarak, etkili kullanım biçimleri oluşturulmalıdır. Öğretim elemanları, eğitimde sosyal medyayı etkin kullanma konusunda önlerindeki engelleri kaldırmak adına bu desteğe ihtiyaç duymaktadırlar (Gülbahar ve ark., 2017; Neier ve Zayer, 2015; Rochez, 2015; Smith, 2016).

BÖTE bölümünde çalışan araştırmacıların sosyal medyayı daha etkili kullandıkları, gençlerin sosyal medyadan daha fazla faydalandıkları ve daha fazla yararlanmayı düşündükleri görülmüştür. Benzer şekilde alan yazında genç neslin bu bilgi yolculuğuna dijital yerliler olarak başladıklarından daha fazla deneyime sahip oldukları ve yaşlı eğitmenlerin bu konuda sorun yaşadıkları belirtilmektedir (Hanson ve ark., 2011; Wankel, 2009). Çalışmada katılımcıların sosyal medyayı ayrıntılı olarak kullanmaları durumunda, bu ayrıntılı özellikleri kendi eğitim çalışmalarında da kullanmak istedikleri bulunmuştur. Dahlstrom (2012: akt. Cao ve ark., 2013) 'a göre öğretim üyeleri sosyal medyayı farklı şekilde benimserler ve uyum durumları yaşlarına göre değişir. Gençlerin sosyal medya araçlarını benimseme eğilimi daha yüksek görülmektedir. Başka çalışmalarda da (Manca ve Ranieri, 2016; 2017) akademisyenler açısından disiplin ve yaşın eğitimde sosyal medyayı kullanmanın önemli faktörleri olduğuna işaret edilmektedir.

Sosyal medyanın eğitimde paylaşım, sosyal destek ve firsatları artırma gibi çeşitli kullanımlarının olduğu literatürde yer almaktadır (McLoughlin ve Lee, 2007; Muijs, West ve Ainscow, 2012). Bu çalışmada, araştırmacılar, eğitim çalışmalarında sosyal medyanın kullanılmasının en önemli avantajları olarak; geniş kitlelere ulaşılması, günümüz şartlarına uygunluğu, etkili olması, katılımcılığı ve uygulama kolaylığını belirtmişlerdir. Sınırlılıklar olarak ise belirli bir kitle ya da içeriğe uygun olması, alan yazın eksikliği ve sosyal medyanın güvenilir bir ortam olmayışı gösterilmiştir. Sosyal medyanın araştırma ortamı olarak kullanılacağı araştırmalarda en önemli konulardan biri araştırmanın nasıl tasarlanacağıdır. Çevrimiçi araştırma modelleri, sosyal bilimler araştırmaları açısından önemli firsatlar yaratmasına karşın bu araştırma modelleri literatürde yeterince açıklanmamıştır (Hookway, 2008). Genel olarak, İnternet üzerinden veri toplamak açısından nitel ve nicel araştırmaların çeşitli yöntemlerle gerçekleştirilebileceği belirtilmektedir (Hookway, 2008; Wilkinson ve Thelwall, 2011). Farklı alanlarda yapılan çalışma örneklerine bakıldığında, Eysenbach ve Till (2001), sağlık disiplinde İnternet üzerindeki mesaj ya da gönderi kayıtlarının nitel araştırmalar açısından erişilebilir olduğunu vurgularken Back (2013) da ekonomi alanında güven kazanımı, veri üçlemesi ve tutarlı gözlem ile Facebook etkileşimlerinin yurtdışı çalışma konusunda önemli bir veri sağlayacağına işaret etmektedir. Bu çalışmada, eğitim araştırmacılarının, sosyal medya kullanacakları eğitim araştırmaları için veri toplamada karma yöntemi tercih ettikleri bulunmuştur. Katılımcılar ayrıca araştırma sorusunun ve güvenilirliğin de önemli olduğunu belirtmişler ve sosyal medyanın kullanılacağı bir eğitim araştırması için deneysel model kullanma eğilimine sahip olduklarını ifade etmişlerdir. Özgünlük ve uygulama kolaylığ 1 da dikkat edilmesi gereken diğer konular olarak belirtilmiştir.

Eğitim araştırmacılarının sosyal medya kullanım durumlarını ve eğitsel çalışmalarda sosyal medyanın kullanımına yönelik keşfedici türde gerçekleştirilen çalışmanın sonuçlarını şu şekilde sıralayabiliriz; 
- Eğitim araştırmacıları Web 2.0 ve sosyal medya ile ilgili genel bilgiye sahiplerdir. Ancak, sosyal medyanın işlevselliğini sağlayan teknik boyut hakkında fazla bilgileri yoktur.

- Sosyal medyanın eğitsel çalışmalarda kullanılması konusundaki kuramsal temel eksikliğine rağmen eğitim araştırmacıları gelecek çalışmalarında sosyal medyadan faydalanmayı planlamaktadırlar.

- Eğitim araştırmacılarının çoğunluğu sosyal medya hesaplarına sahiptir. Ancak sosyal medya üzerinde etkin bir katılım gerçekleştirmemektedirler. Genellikle forumları takip etme ve anlık mesajlaşma sistemlerini kullanma eğilimi göstermektedirler.

- Eğitsel çalışmalarda çoğunlukla sosyal ağlar kullanılmaktadır. Forumlar ve anlık mesajlaşma sistemleri ise sosyal ağlardan hemen sonra gelmektedir.

- Eğitim araştırmacıları iyi bildikleri ve günlük yaşamlarında kullandıkları sosyal medya ögelerinden eğitim çalışmalarında daha fazla yararlanma eğilimindedirler. Aynı zamanda sosyal medyayı daha etkin kullanan eğitim araştırmacıları eğitim çalışmalarında sosyal medya ögelerini daha yoğun kullanma düşüncesindedirler.

- Bilgi ve iletişim teknolojilerini kullanma yeteneği eğitim araştırmalarında sosyal medyayı kullanma üzerinde herhangi bir etki yaratmamaktadır.

- Aynı bölümde görev yapan eğitim araştırmacıları sosyal medya, Web 2.0 ve bloglar hakkında eşit bilgi düzeyine sahiptirler. Bölümler arasında en fazla bilgi ve kullanım eğilimine BÖTE akademisyenleri sahiptir.

- Genç eğitim araştırmacıları sosyal medyadan eğitim çalışmalarında kullanma konusunda daha isteklidirler.

- Sosyal medyanın eğitim çalışmalarına sağladığı katkılar arasında geniş kitlelere ve verilere erişim, güncel ve etkili olması, katılımcılığı sağlaması ve uygulama kolaylığı görülmektedir.

- Eğitim çalışmalarında sosyal medya kullanımı konusundaki sınırlılıklar açısından güvenirlik, alan yazın eksikliği, belli bir kitle ve içeriğe uygunluğu ifade edilmektedir.

- Eğitim araştırmacıları sosyal medya kullanılacak eğitsel çalışmalarda araştırma modeli olarak deneysel deseni tercih etmektedirler. Araştırma tasarımı açısından güvenirlik ve araştırma sorusuna dikkat etmektedirler. Veri toplama yöntemleri açısından ise nitel ve nicelin birbirini tamamlaması göz önüne alınarak karma yöntem seçme eğilimi ön planı çıkmaktadır.

Araştırma kapsamı, sınırlılıkları ve sonuçlarına bağlı olarak aşağıdaki öneriler sunulabilir.

- Eğitim araştırmacıları eğitim çalışmalarında sosyal medyadan yararlanma konusunda isteklidirler. Araştırmacılar genellikle iyi bildikleri ve kullandıkları sosyal medya ögelerinden daha fazla yararlanma eğilimindedirler. Sosyal medyanın etkin ve doğru kullanımı açısından eğitim araştırmacılarına teknik konularda ve öğretim süreçlerine entegrasyonu hakkında üniversitelerdeki alan uzmanları tarafından tanıtım ve bilgilendirme seminerleri düzenlenebilir.

- Eğitim araştırmacıları genel olarak sosyal medya üzerinde etkin bir profil çizmemektedirler. Bununla beraber sosyal medyayı daha yoğun kullanan araştırmacıların eğitim araştırmalarında da daha fazla yararlandıkları görülmüştür. Bundan dolayı Cao ve diğerleri (2013), Chen ve Bryer (2012) ve Gao ve arkadaşlarının (2012) da ifade ettiği gibi eğitim araştırmacıları, öğretim süreçlerinde öğrenci memnuniyetini ve öğrenme çıktılarını arttırmak adına sosyal medya teknolojilerini benimsemeye ve kullanmaya teşvik edilebilirler.

- Gerçekleştirilen bu keşfedici araştırma sonrası diğer araştırma türlerinde de detaylı çalışmalar gerçekleştirilebilir. Böylece sosyal medyanın bir araştırma ya da öğretim ortamı olarak farklı kullanımlarına ilişkin çeşitli örnekler eğitimcilere sunulabilir (Chen ve Bryer, 2012; Veletsianos ve diğ., 2013). Aynı zamanda Türk kültürü içerisinde sosyal medyanın eğitim çalışmalarında kullanılmasına ilişkin model çalışmalarına zemin hazırlanabilir.

- Yoo ve Huang (2011), kültürel farklılığın öğrencilerin teknolojiyi nasıl kabul ettiklerini ve bu farklı kullanımın öğrenmeyi etkileyebileceğini, bu değişikliklerin bilinmesinin eğitimcilerin uygun Web 2.0 
araçlarını eğitim ortamlarına verimli bir şekilde entegre etmelerine yardımcı olabileceğini belirtmişlerdir. Benzer şekilde, Donelan (2016) da kültürün bilişim teknolojileri ve sosyal medya kullanımı üzerinde etkili olduğunu belirtmektedir. Bu nedenle, gelecekteki çalışmalarda kültür farklılıklarının da dikkate alınması önerilebilir.

\section{References}

Ada, M. B., Stansfield, M., \& Baxter, G. (2017). Using mobile learning and social media to enhance learner feedback: Some empirical evidence. Journal of Applied Research in Higher Education, 9(1), 70-90. DOI: 10.1108/JARHE-07-2015-0060

Ajjan, H., \& Hartshorne, R. (2008). Investigating faculty decisions to adopt Web 2.0 technologies: Theory and empirical tests. Internet and Higher Education 11(2), 71-80.

Al-Bahrani, A., Patel, D., \& Sheridan, B. (2015). Engaging students using social media: The students' perspective. International Review of Economics Education, 19, 36-50.DOI:10.1016/j.iree.2015.06.001

Albion, P. (2008). Web 2.0 in teacher education: Two imperatives for action. Computers in the Schools 25(3/4), 181-198.

Amador, P., \& Amador J. (2014). Academic advising via Facebook: Examining student help seeking. The Internet and Higher Education, 21, 9-16. DOI: 10.1016/j.iheduc.2013.10.003

Aspey, S. (2011). New survey finds more than ninety Percent of college faculty use social media in the workplace. PR Newswire [New York], 11 April. Accessed 23 January, 2018. http://www.prweb.com/releases/college_faculty/social_media/prweb5240914.htm

Aydin, S. (2012). A review of research on Facebook as an educational environment. Educational Technology Research \& Development, 60, 1093-1106.

Back, M. (2013). Using Facebook data to analyze learner interaction during study abroad. Foreign Language Annals, 46(3), 377-401.

Borštnar, M. K. (2012). Towards understanding collaborative learning in the social media environment. Organizacija, 45(3), 100-107.

Bozanta, A., \& Mardikyan, S. (2017). The effects of social media use on collaborative learning: A case of Turkey. Turkish Online Journal of Distance Education-TOJDE, 18(1), 96-110.

Brech, F. M., Messer, U., Schee, B. A.V., Rauschnabel, P. A., \& Ivens, B. S. (2017). Engaging fans and the community in social media: Interaction with institutions of higher education on Facebook. Journal of Marketing for Higher Education, 27(1), 112-130. DOI: 10.1080/08841241.2016.1219803

Callaghan, N., \& Bower, M. (2012). Learning through social networking sites - the critical role of the teacher. Educational Media International, 49(1), 1-17.

Cao, Y., Ajjan, H., \& Hong, P. (2013). Using social media applications for educational outcomes in college teaching: A structural equation analysis. British Journal of Educational Technology, 44(4), 581-593.

Castro, J. C. (2012). Learning and teaching art: Through social media. Studies in Art Education, 53(2), 152-169.

Chen, B., \& Bryer, T. (2012). Investigating instructional strategies for using social media in formal and informal learning. The International Review of Research in Open and Distance Learning, 13(1), 87-104.

Chu, S. K. W., Capio, C. M., van Aalst, J. C. W., \& Cheng, E. W. L. (2017). Evaluating the use of a social media tool for collaborative group writing of secondary school students in Hong Kong. Computers \& Education, 110, 170-180. DOI: 10.1016/j.compedu.2017.03.006

Conway, M. (2011). Book review: Educating educators with social media, Charles Wankel. On the Horizon, 19(4), 350-354.

Çelik, İ., Kaplan Akıllı, G., \& Onuk, C. (2014). Social media for academics: Motivation killer or booster? Paper presented at the IEEE 14th International Conference on Advanced Learning Technologies, ICALT 2014, Athens, Greece, 7-10 July 2014.

Dabbagh, N., \& Kitsantas, A. (2012). Personal Learning Environments, social media, and self-regulated learning: A natural formula for connecting formal and informal learning. Internet and Higher Education, 15, 3-8.

Donelan, H. (2016). Social media for professional development and networking opportunities in academia. Journal of Further and Higher Education, 40(5), 706-729. DOI: 10.1080/0309877X.2015.1014321

Eysenbach, G., \& Till, J. E. (2001). Ethical issues in qualitative research on internet communities. British Medical Journal, 323, 1103-1105. 
Evans, C. (2014). Twitter for teaching: Can social media be used to enhance the process of learning? British Journal of Educational Technology, 45(5), 902-915. DOI: 10.1111/bjet.12099

Ferriter, W. M. (2010-2011). Digitally speaking / Using social media to reach your community. Educational Leadership / The Effective Educator (December 2010 / January 2011), 68(4), 87-88.

Frankel, M. S., \& Siang, S. (1999). Ethical and legal aspects of human subjects' research on the Internet. Accessed 11 February, 2017. http://www.aaas.org/spp/sfrl/projects/intres/report.pdf

Friesen, N., \& Lowe, S. (2012). The questionable promise of social media for education: connective learning and the commercial imperative. Journal of Computer Assisted Learning, 28, 183-194.

Galiatsatos, P., Porto-Carreiro, F., Hayashi, J., Zakaria, S., \& Christmas, C. (2016). The use of social media to supplement resident medical education - the SMART-ME initiative. Medical Education Online, 21(1): 29332. DOI: $10.3402 / \mathrm{meo} . \mathrm{v} 21.29332$

Gao, F., Luo, T., \& Zhang, K. (2012). Tweeting for learning: A critical analysis of research on microblogging in education published in 2008-2011. British Journal of Educational Technology, 43(5), 783-801.

Garcia, L. S., \& Costa Silva, C. M. (2017). Differences between perceived usefulness of social media and institutional channels by undergraduate students. Interactive Technology and Smart Education, 14(3), 196-215. DOI: 10.1108/ITSE-01-2017-0009

Gonzales L., Vodicka, D., \& White, J. (2011). Leadership 2.0 social media in advocacy. Leadership, 41(1), 18-38.

Gülbahar, Y., Rapp, C., Kilis, S., \& Sitnikova, A. (2017). Enriching higher education with social media: Development and evaluation of a social media toolkit. International Review of Research in Open and Distributed Learning, 18(1), 23-39.

Güler, K. (2015). Social media-based learning in the design studio: A comparative study. Computers \& Education, 87, 192-203. DOI: 10.1016/j.compedu.2015.06.004

Greenhow, C., \& Lewin, C. (2016). Social media and education: Reconceptualizing the boundaries of formal and informal learning. Learning, Media and Technology, 41(1), 6-30. DOI: 10.1080/17439884.2015.1064954

Grosseck, G., \& Holotescu, C. (2011). Academic research in 140 characters or less. Paper presented at the 7th International Scientific Conference eLearning and Software for Education, Bucharest, Romania, April 28-29.

Hanson, C., West, J., Neiger, B., Thackeray, R., Barnes, M., \& McIntyre, E. (2011). Use and acceptance of social media among health educators. American Journal of Health Education, 42(4), 197-204.

Hookway, N. (2008). 'Entering the blogosphere': Some strategies for using blogs in social research. Qualitative Research, 8(1), 91-113.

Kaplan, A. M., \& Haenlein, M. (2010). Users of the world, unite! The challenge and opportunities of social media. Business Horizons, 53(1), 59-68. DOI: 10.1016/j.bushor.2009.09.003

Kimmons, R., \& Veletsianos, G. (2016). Education scholars' evolving uses of twitter as a conference backchannel and social commentary platform. British Journal of Educational Technology, 47(3), 445-464. DOI: $10.1111 /$ bjet.12428

Knight, C. G., \& Kaye, L. K. (2016). 'To tweet or not to tweet?' A comparison of academics' and students' usage of Twitter in academic contexts. Innovations in Education and Teaching International, 53(2), 145-155. DOI: $10.1080 / 14703297.2014 .928229$

Lamb, A., \& Johnson, L. (2007). Social technology and social networks. School Library Monthly 23(5), 40-44.

Li, J., \& Greenhow, C. (2015). Scholars and social media: tweeting in the conference backchannel for professional learning. Educational Media International, 52(1), 1-14. DOI: 10.1080/09523987.2015.1005426

Maloney, S., Moss, A., \& Ilic, D. (2014). Social media in health professional education: a student perspective on user levels and prospective applications. Advances in Health Sciences Education, 19, 687-697. DOI: 10.1007/s10459-014-9495-7

Manca, S., \& Ranieri, M. (2016). "Yes for sharing, no for teaching!": Social Media in academic practices. Internet and Higher Education, 29, 63-74. DOI: 10.1016/j.iheduc.2015.12.004

Manca, S., \& Ranieri, M. (2017). Networked scholarship and motivations for social media use in scholarly communication. International Review of Research in Open and Distributed Learning, 18(2), 123-138.

Matzat, U., \& Vrieling, E. M. (2016). Self-regulated learning and social media - a 'natural alliance'? Evidence on students' self-regulation of learning, social media use, and student-teacher relationship. Learning, Media and Technology, 41(1), 73-99. DOI: 10.1080/17439884.2015.1064953

Mazman, S. G., \& Koçak Usluel, Y. (2010). Modeling educational usage of Facebook. Computers \& Education, 55, 444-453.

McLoughlin, C., \& Lee, J. W. (2007). Social software and participatory learning: pedagogical choices with technology affordances in the web 2.0 era. Paper presented at the Ascilite, Singapore 2007, December 2-5. 
Meishar-Tal, H., Kurtz, G., \& Pieterse, E. (2012). Facebook groups as LMS: A case study. The International Review of Research in Open and Distance Learning 13(4): 33-48.

Moll, R., \& Nielsen, W. (2017). Development and validation of a social media and science learning survey. International Journal of Science Education, Part B: Communication and Public Engagement, 7(1), 14-30. DOI: $10.1080 / 21548455.2016 .1161255$

Muijs, D., West, M., \& Ainscow, M. (2012). Why network? Theoretical perspectives on networking. School Effectiveness and School Improvement, 21(1), 5-26.

Murthy, D. (2008). Digital ethnography: An examination of the use of new technologies for social research. Sociology, 42(5), 837-855.

Neier, S., \& Zayer, T. (2015). Students' perceptions and experiences of social media in higher education. Journal of Marketing Education, 37(3), 133-143. DOI: 10.1177/0273475315583748

O’Boyle, I. (2014). Mobilising social media in sport management education. Journal of Hospitality, Leisure, Sport \& Tourism Education, 15, 58-60. DOI: 10.1016/j.jhlste.2014.05.002

Pimmer, C., Linxen, S., \& Gröhbiel, U. (2012). Facebook as a learning tool? A case study on the appropriation of social network sites from mobile phones in developing countries. British Journal of Educational Technology, 43(5), 726-738. DOI: 10.1111/j.1467-8535.2012.01351.x

Poellhuber, B., \& Anderson, T. (2011). Distance students' readiness for social media and collaboration. The International Review of Research in Open and Distance Learning, 12(6), 102-125.

Popa, D., \& Voinea, M. (2017). Social media - new form of learning community. The European Proceedings of Social \& Behavioural Sciences EpSBS, 23, 1842-1850. DOI: 10.15405/epsbs.2017.05.02.226

Poynter, R. (2010). The handbook of online and social media research: Tools and techniques for market researchers. UK: John Wiley \& Sons Ltd.

Prensky, M. (2001a). Digital natives, digital immigrants, Part 1. On the Horizon, 9(5), 1,3-6. DOI: $10.1108 / 10748120110424816$

Prensky, M. (2001b). Digital natives, digital immigrants, Part II: Do they really think differently? On the Horizon, 9(6), 1,3-6. DOI: 10.1108/10748120110424843

Prensky, M. (2005). Listen to the natives. Educational Leadership, 63(4), 8-13.

Reiter, B. (2017). Theory and methodology of exploratory social science research. International Journal of Science and Research Methodology, 5(4), 129-150.

Rochez, C. (2015). Historians of education and social media. History of Education, 44(4), 405-414. DOI: 10.1080/0046760X.2015.1036137

Roy, D., Taylor, J., Cheston, C. C., Flickinger, T. E., \& Chisolm, M. S. (2016). Social media: Portrait of an emerging tool in medical education. Academic Psychiatry, 40, 136-140. DOI: 10.1007/s40596-014-0278-5

Sanchez, R. A., Cortijo, V., \& Javed, U. (2014). Students' perceptions of Facebook for academic purposes. Computers \& Education, 70, 138-149. DOI: 10.1016/j.compedu.2013.08.012

Sarapin, S. H., \& Morris, P. L. (2015). Faculty and Facebook friending: Instructor-student online social communication from the professor's perspective. The Internet and Higher Education, 27, 14-23. DOI: 10.1016/j.iheduc.2015.04.001

Selwyn, N. (2007). Screw Blackboard ... do it on Facebook!: An investigation of students' educational use of Facebook. Paper presented to the Poke 1.0 - Facebook social research symposium, University of London, November 15.

Smith, E. E. (2016). “A real double-edged sword:” Undergraduate perceptions of social media in their learning. Computers \& Education, 103, 44-58. DOI: 10.1016/j.compedu.2016.09.009

Smith, S., Salaway, S., \& Caruso, J. B. (2009). The ECAR study of undergraduate students and information technology, Boulder, CO: EDUCAUSE Center for Applied Research. Accessed 20 July, 2017, http://www.educause.edu/library/resources/ecar-study-undergraduate-students-and-information-technology2009

Sullivan, J. (2017). China scholars and Twitter. Research Report. Downloaded from https://www.cambridge.org/core. DOI: 10.1017/S0305741017000017

Tyson, W. (2010). Pitch Perfect: Communicating with traditional and social media for scholars, researchers, and academic leaders. Virginia: Stylus Publishing.

Veletsianos, G. (2013). Open practices and identity: Evidence from researchers and educators' social media participation. British Journal of Educational Technology 44(4): 639-651. 
Veletsianos, G., \& Kimmons, R. (2016). Scholars in an increasingly open and digital world: How do education professors and students use Twitter? Internet and Higher Education, 30, 1-10. DOI: 10.1016/j.iheduc.2016.02.002

Veletsianos, G., Kimmons, R., \& French, K. D. (2013). Instructor experiences with a social networking site in a higher education setting: expectations, frustrations, appropriation, and compartmentalization. Educational Technology Research \& Development, 61, 255-278.

Wang, C. M., (2012). Using Facebook for cross-cultural collaboration: the experience of students from Taiwan. Educational Media International, 49(1), 63-76.

Wankel, C. (2009). Management education using social media. Organization Management Journal, 6(4), $251-262$.

Wilkinson, D., \& Thelwall, M. (2011). Researching personal information on the public web: Methods and ethics. Social Science Computer Review, 29(4), 387-401.

Yoo, S. J., \& Huang, W. H. D. (2011). Comparison of web 2.0 technology acceptance level based on cultural differences. Educational Technology \& Society, 14(4), 241-252. 